\title{
Interim Reclamation Report: Basalt Waste Isolation Project Exploratory Shaft Site
}

C. A. Brandt

W. H. Rickard, Jr.

M. G. Hefty

February1990

Prepared for the U.S. Department of Energy under Contract DE-AC06-76RLO 1830

Pacific Northwest Laboratory Operated for the U.S. Department of Energy by Battelle Memorial Institute 


\title{
DISCLAIMER
}

This report was prepared as an account of work sponsored by an agency of the United States Government. Neither the United States Government nor any agency thereof, nor Battelle Memorial Institute, nor any of their employees, makes any warranty, expressed or lmplied, or assumes any legal iability or responsibility for the accuracy, completeness, or usefulness of any information, apparatus, product, or process dbclosed, or represents that its use would not infinge prtvately owned rights. Reference herein to any specific commercial product, process, or service by trade name, tradernark, manufacturer, or otherwise, does not necessarily constitute or imply its endorsement, recommendation, or favoring by the United States Government of any agency thereof, or Battelle Memorial Institute. The views and opinions of authors expressed herein do not necessarily state or reflect those of the United States Government or any agency thereof.

\author{
PACIFIC NORTHWEST LABORATORY \\ operated by \\ BATTELLE MEMORIAL INSTITUTE \\ for the \\ UNITED STATES DEPARTMENT OF ENERGY \\ under Contract DE-ACO6-76RLO 1830
}

Printed in the United States of America

Available to DOE and DOE contractors from the

Office of Scientific and Technical Information, P.O. Box 62, Oak Ridge, TN 37831; prices available from (615) 576-8401. FTS 626-8401.

Available to the public from the National Technical Information Service, U.S. Department of Commerce, 5285 Port Royal Rd., Spring field, VA 22161.

NTIS Price Codes, Microfiche A01

Printed Copy

\begin{tabular}{cr}
\hline Price Code & Page Range \\
\hline A02 & $1-10$ \\
A03 & $11-50$ \\
A04 & $51-75$ \\
A05 & $76-100$ \\
A06 & $101-125$ \\
A07 & $126-150$ \\
A08 & $151-175$ \\
A09 & $176-200$ \\
A10 & $201-225$ \\
A11 & $226-250$ \\
A12 & $251-275$ \\
A13 & $276-300$ \\
A14 & $301-325$
\end{tabular}

\begin{tabular}{cc}
\hline Price Code & Page Range \\
\hline A15 & $326-350$ \\
A16 & $351-375$ \\
A17 & $376-400$ \\
A18 & $401-425$ \\
A19 & $426-450$ \\
A20 & $451-475$ \\
A21 & $476-500$ \\
A22 & $501-525$ \\
A23 & $526-550$ \\
A24 & $551-575$ \\
A25 & $576-600$ \\
A99 & $601-U p$
\end{tabular}


INTERIM RECLAMATION REPORT:

BASALT WASTE ISOLATION PROJECT

EXPLORATORY SHAFT SITE

\author{
C. A. Brandt \\ W. H. Rickard, Jr. \\ M. G. Hefty
}

February 1990

Prepared for

the U.S. Department of Energy

under Contract DC-AC06-76RLO 1830

Pacific Northwest Laboratory

Richland, Washington 99352 


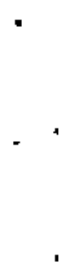




\section{SUMMARY}

In 1968, a program was started to assess the feasibility of storing Hanford Site defense waste in deep cavems constructed in basalt. This program was expanded in 1976 to include investigations of the Hanford Site as a potential location for a mined commercial nuclear waste repository. Extensive sudies of the geolechnical aspecis of the site were undertaken, including preparations for drilling a large diameter $(2.8 \mathrm{~m})$ Exploratory Shaft to a depth of 1158 m. On December 22, 1987, President Reagan signed into law the Nuclear Waste Poticy Amendments Act of 1987, which effectively stopped all repository-related activities except reclamation of disturbed lands at the Hanford Site.

This repon describes the development of the reclamation program for the Exploratory Shaft Facility, its implementation, and preliminary estimates of its success. The goal of the reclamation program is to return sites disturbed by the repository program as nearly as practicable to their original conditions using native plant species.

Constraints on the reclamation program include climatic factors, edaphic (soil) characteristics, competition from native and non-native species, and seed germination and growth characteristics of the desired species. The Exploratory Shaft Facility experiences a net input to soil moisure between November and Febrary and a severe moisture deficit from July to October. Summer storms occasionally drop large amounts of moisture, but these are very infrequent and cannot be relied on to sustain plant growth. Precipitation during any period is uureliable: droughts have occurred in 1 of 5 years. Temperatures during the winter months are usually not so low as to preclude soine plant growth at that time: indeed most of the shrubs and grasses are physiologically very active during this period. However, arctic air masses occasionally push the temperatures down to $-20^{\circ} \mathrm{C}$ or $-30^{\circ} \mathrm{C}$. At these temperatures, damage to unprotected growing plants may be severe. The transition period between March and June may be of primary importance to plant establishment. Temperatures ameliorate greally from the winter lows, and moisture inputs usually increase. However, $15 \%$ of years since 1912 have failed to receive $2.5 \mathrm{~cm}$ of precipitation during this period. Thus, providing adequate moisture to revegetated plants will be a critical to their success, at least during the first growth year. The soil of the Exploralory Shaff Facility is mapped as Hezel Sand, thus water-holding capacity is expected to be low.

The Exploratory Shaft Facility is surrounded by a big sagebrush-cheatgrass community. The shrub component is dominated by big sagebrush (Artemisia tridentata) and grey rabbitbrush (Chrysothamnus nauseosus). Other shrub components include green rabbitbrush (C. viscidiflorus) and spiny hopsage (Atriplex spinosa). Cheatgrass (Bromus tectorwm) dominated the understory, though Sandberg bluegrass, bottlebrush squirreltail, and needle-and-thread were also present.

Demolition of the Exploratory Shaft Facility began in April 1988. All equipment, buildings, utilities, roadways, and gravels were removed. However, the reinforced concrete collar supporting the drill rig was not removed, but was disposed of in place. Because there was insufficient soil present to build a mound of soil over the collar and fill the large mud pit south of the drill rig, gravel was retained from the top course to build the mound.

Revegetation began in November 1988. Soil compaction was relieved by disking to a depth of $15 \mathrm{~cm}$. Seeding consisted first of broadcasting seeds of Chrysothamnks spp. and Artemisia tridentata, followed by drilling of Sandberg bluegrass and botlebrush squirreltail (Sitanion hystrix). A mulch of certified weed-free straw was then blown over the seedbed at a rate of $9000 \mathrm{~kg} / \mathrm{ha}$, which was twice the recommended rate. Six-inch $(15-\mathrm{cm})$ tubeling spiny luopsage were planted between March 8 and 15, 1989. Plants were set in the ground in a clumped configuration with each plant set in a depression at least $2.5 \mathrm{~cm}(1 \mathrm{in})$ below grade. The sile was irrigated using hand-move sprinklers during March to June 1989. Irrigation was done at the end of each month sufficient to make the cumulative precipitation on the site reach $2.5 \mathrm{~cm}$ ( 1 in) per month.

In order to track the development of vegetarion in the target habitats, data on percent cover and plant density were obtained from the four control plots located around the Exploratory Shaft Facility in May and June 1988. Nalive grasses composed relatively little of the ground cover in the undisturbed habitat. Cheatgrass, which occurred in all plots, grew rapidly between April and June, going from nearly $28 \%$ to nearly $50 \%$ of the ground cover in that time period. Vegetative growth on the revegetated areas was measured on March 30, 1989, by a stratified random 
sampling of 60 plot frames $\left(0.25 \mathrm{~m}^{2}\right)$. The density of nacive grasses on the overflow pond area was greater on average than elsewhere. Grass on the mound was shorter than grass elsewhere, though the difference was not statistically significant Survival of spiny hopsage tubelings was determined by walking eight east-west transects across the Exploratory Shaft Facility area, noting the number of planted shrubs along the transect and indicating which appeared alive and which did noL. Transects were surveyed on July 13, 1989. Overall, apparent hopsage mortality during the first 4 months on the site averaged $51.5 \%$. Mortality was higher in the center of the Exploratory Shaft Facility than at the edges.

As of March 1989, cover by seeded grasses was consistent with the reclamalion objective. Emergence was spotty, with many plots showing no grasses at all. Growth of grasses on the mound was poorer than elsewhere, though emergence rates were no different. An extremely low-temperature arctic air mass entered the Pasco Basin in February, with temperauures below $-25^{\circ} \mathrm{C}$. Most of the grasses showed frost burns from this low-temperature event. Damage appeared sufficiently severe that many plants deemed alive at the end of March were unlikely to survive another month. Whether or not sufficient grasses survive cannot be assessed until the fall 1989 growth period. 


\section{ACKNOWLEDGMENTS}

The reclamation program for the Basalt Waste Isolation Project (BWIP) involved the cooperative effors of the U.S. Department of Energy (DOE), Westinghouse Hanford Company, Morrison-Knudsen, and the Pacific Northwest Laboratory (PNL). Those persons at PNL, excluding the authors, who were involved in the development and implementation of the reclamation program include Carol Schuler, Tom Page, Bob Newell, and Jim States. Ray Bienert and Natalie Cadoret later became heavily involved in the project both in the field and in managing the data. We appreciate the respect our recomınendations for reclamation were given by Westinghouse Hanford Company and DOE management involved with the BWIP reclamation program. We think the initial success of the reclamation effort reflects their trust. 


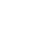




\section{CONTENTS}

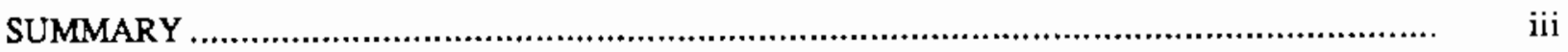

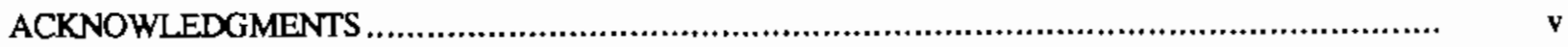

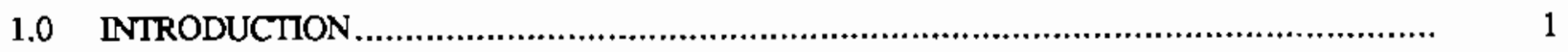

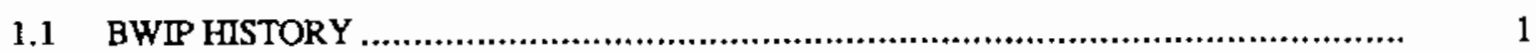

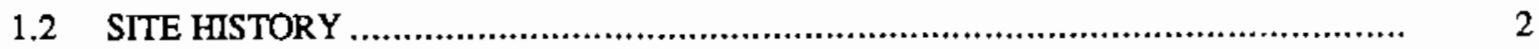

1.2.1 Pre-Nuclear History .......................................................................

1.2.2 Nuclear (Since 1943) History................................................................ 2

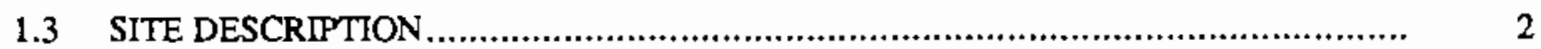

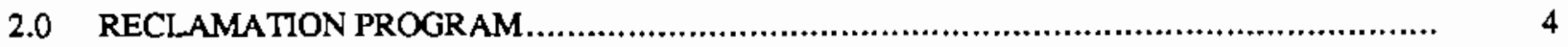

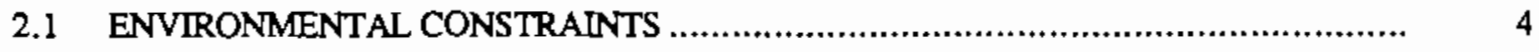

2.1.1 Climate........................................................................................

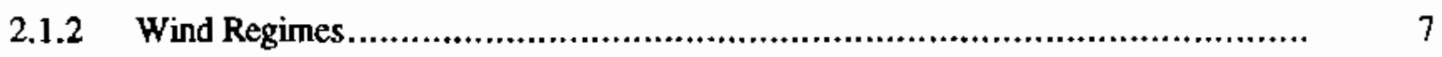

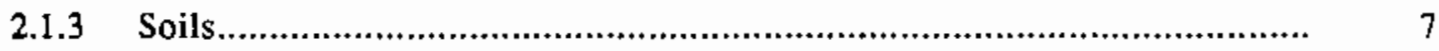

2.1.4 Plant Communities ......................................................................... 8

2.2 DERIVATION OF RECOMMENDATION FOR RECLAMATION............................ 10

2.2.1 Identification of Existing Site Conditions ................................................. 10

2.2.2 Revegetation Methods and Materials ....................................................... 10

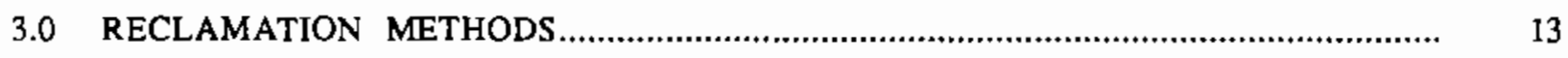

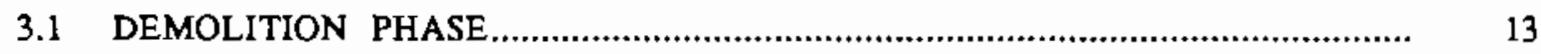

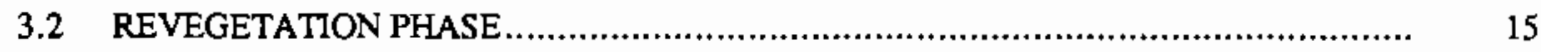

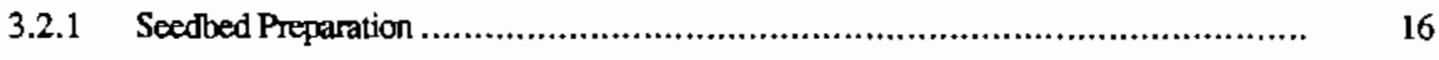

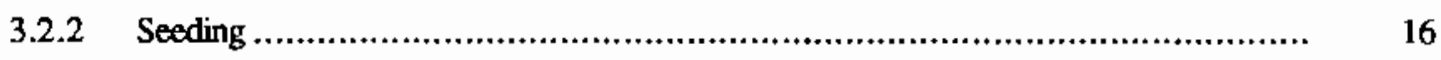

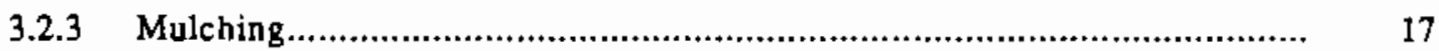

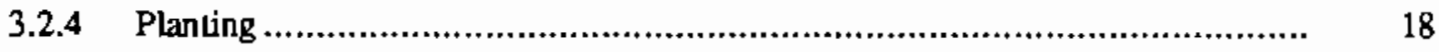

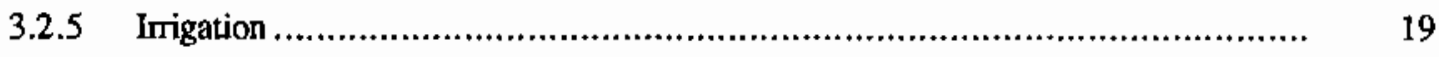




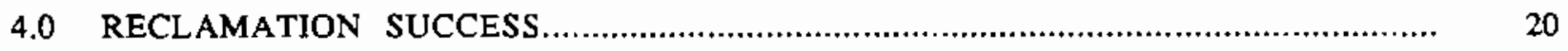

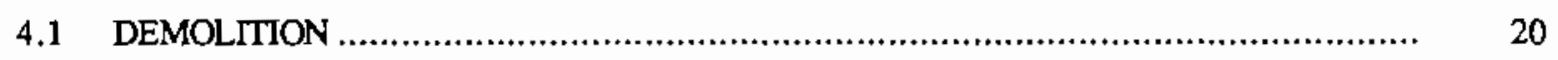

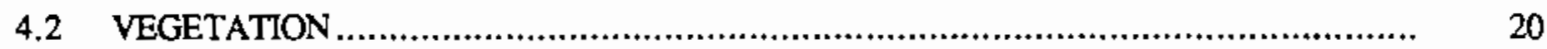

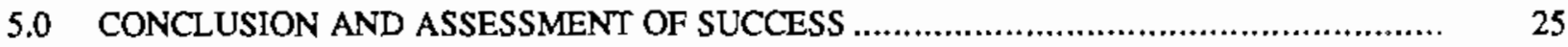

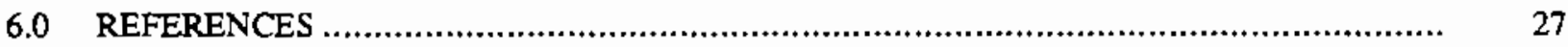

APPENDIX A - DATA ON UNDISTURBED HABITATS AT THE ESF

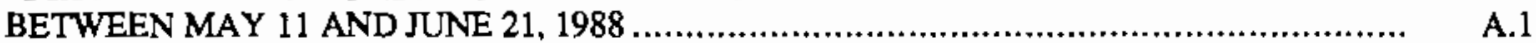

APPENDIX B - DATA ON UNDISTURBED HABITATS AT THE ESF

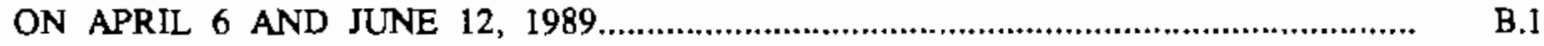

APPENDIX C - SUMMARY OF GROWTH PARAMETERS OF GRASSES

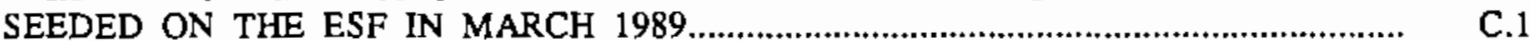




\section{FIGURES}

1 Location of the Reference Repository Location and the Hanford Sile .................................... 3

2 Normal and Extreme Daily Temperatures at Hanford......................................................... 5

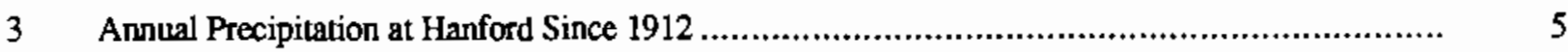

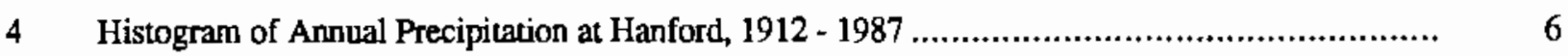

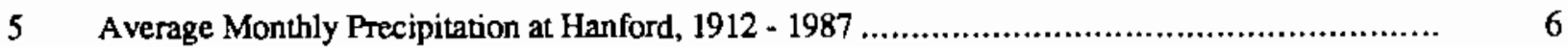

6 Average Temperature and Precipitation Profiles for Three Periods of the Year.............................. 6

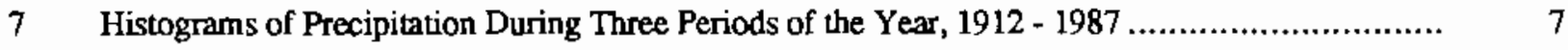

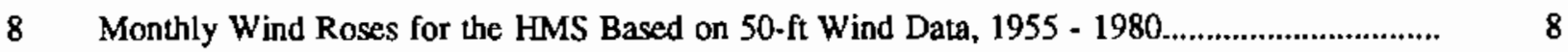

9 Aerial Photograph of the Exploratory Shaft Facility as Constructed ................................... 11

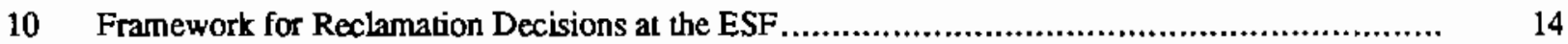

11 Schematic Diagram of Community Time-Transition Trajectories at the ESF ......................... 15

12 Schematic Diagram of Hopsage Clump Densities Planted at the ESF ................................. 18

13 Schematic Diagram of Hopsage Clump Densities Planted at the

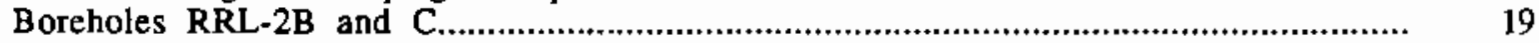

14 Aerial Photograph of the Exploratory Shaft Facility and Associated Boreholes

at Completion of Demolition, December, 1988................................................................. 21

15 Density of Sandberg Bluegrass and Boulebrush Squirreltail (Combined) per $0.25 \mathrm{~m}^{2}$

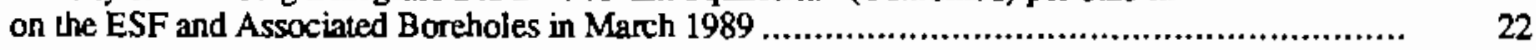

16 Height of Sandberg Bluegrass and Bottlebrush Squirreltail (Combined) in $0.25 \mathrm{~m}^{2}$

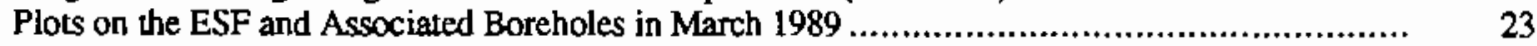

17 Average Number of Leaves of Sandberg Bluegrass and Bottlebrush

Squirreltail (Combined) in $0.25 \mathrm{~m}^{2}$ Plots on the ESF and Associated Boreholes in March 1989.

18 Average Monality of Tubeling Hopsage Between Planting in March and

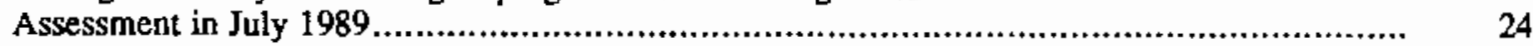

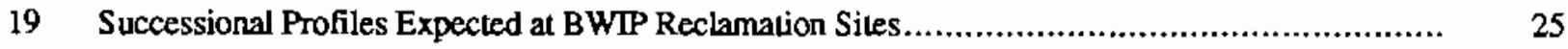




\section{TABLES}

1 Average Cover and/or Plant Density for Species in Undisurbed Plots Located

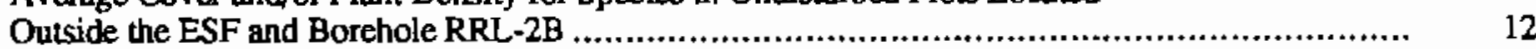

2 Soil Parameters from Undisturbed Soils Surrounding the ESF .........................................

3 Site-specific Constraints and Considerations and Their Solutions to be Implemented

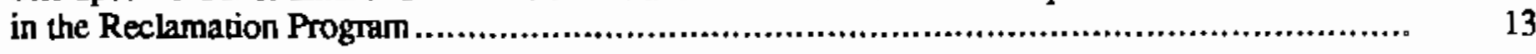

4 Soil Parameters at Three Locations Within the ESF at Completion of Demolition .................... 16

$5 \quad$ Seeding Mixtures and Specifications for ESF and Boreholes RRL-2B and C ........................ 17

6 Specifications for Seed Used on the ESF and Boreholes RRL-2B and C ............................ 17

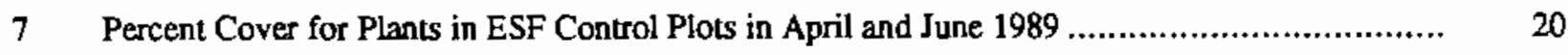

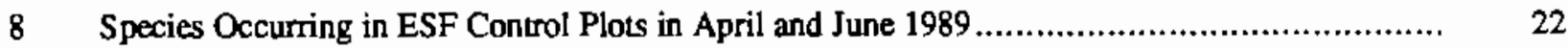

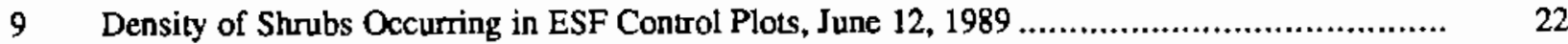




\subsection{INTRODUCTION}

The restoration of areas disturbed by activities of the Basalt Waste Isolation Project (BWTP) conslitules a unique operation at the U.S. Department of Energy's (DOE) Hanford Site, both from the standpoint of restoration objectives and the time frame for accomplishing these objectives. The BWIP reclamation program comprises three separate projects: borehole reclamation, Near Surface Test Facility (NSTF) reclamation, and Exploratory Shaft Facility (ESF) reclamation. This report describes the development of the reclamation progran for the ESF, its implementation, and preliminary estimates of its success.

\subsection{BWIP HISTORY}

In 1968, a program was started to assess the feasibility of storing Hanford Site defense waste in deep caverns constructed in basalt (Deju 1978). In 1976, the National Waste Terminal Slorage Program, initiated by the DOE, expanded the studies of basalt to investigate the potential for a national commercial nuclear waste repository at Hanford. Eight other locations in a variety of host media (i.e., type of rocks) were also defined as possible commercial waste disposal locations by the initial studies (Babad 1985).

On January 7, 1983, President Reagan signed into law the Nuclear Waste Policy Act of 1982 (Public Law 97-425), which mandates the development of repositories in deep geologic formations as the primary disposal strategy for high-level commercial wastes (Babad 1985).

The Nuclear Waste Policy Act of 1982 required DOE to develop specific guidelines for establishing the site of the repository. In December 1984, the DOE published final guidetines for narrowing the nine sites under investigation by DOE to five. The five sites nominated were: Richton Dome, Mississippi; Yucca Mountain, Nevada; Deaf Smith County, Texas; Davis Canyon, Ulah; and the Reference Repository Location on the Hanford Site in Washington State (Babad 1985). The Reference Repository Location was selected in 1981 after extensive geotechnical studies. This location is a 4660 ha site within the Hanford Site that met all of the inilial DOE guidelines for safety that were required before site characterization.

In 1982, a large rotary drill rig was brought to the Reference Repository Location to bore the furst largediameter Exploratory Shaft, which would provide access to the basalt formations at the depth of the proposed repository. The shaft was to be drilled to a depth of more than $1158 \mathrm{~m}$ and a diameter of more than $2.8 \mathrm{~m}$. Horizontal core holes were to be drilled at depth from an underground shaft station to enable testing of the basalt. A starter shaft was drilled to $30 \mathrm{~m}$ (with a steel liner installed and grout placed between the liner and the shaft walls). A drill pad was constructed around the starter shaft, and the rig was assembled to begin drilling the Exploratory Shaft. After drilling the stanter shaft, DOE delayed further drilling.

Two large boreholes were located adjacent to the Exploratory Shaft: these were designaled RRL-2B and RRL-2C. RRL-2B was to be used as the pumping location for the large-scale hydraulic stress test, which was to determine flow parameters of the confined aquifers. Pumped water was to be piped to a bermed pit several hundred yards west of the well site. Aquifer response was to be measured in well RRL-2C.

On December 22, 1987, President Reagan signed into law the Nuclear Waste Policy Amendments Act of 1987 that provided, among other things, that DOE must 1) proceed with the orderly phase out of all site characterization activities (other than reclamation aclivities) at all candidate sites except Yucca Mountain and 2) suspend site characterization activities at all candidate sites, except for Yucca Mountain, within 90 days of the date of enactment of the Nuclear Waste Policy Amendments Act of 1987. This law effectively stopped all sile characterization for BWIP at Hanford and established Yucca Mountain, Nevada, as the official site for the repository.

No specific standards and criteria were spelled out in the Nuclear Waste Policy Amendments Act that governed the reclamation of the Hanford Site; therefore, other guidelines and commitments were applied. The Nuclear Waste Policy Act requires DOE to reclaim sites disurbed during civilian radioactive waste management activities. In Section 7.6 of the Nuclear Waste Policy Act document, Mission Plan for the Civilian Radioaclive Waste Management Program 
(DOE 1985), the guidelines for decommissioning sites found unsuitable for repository development are presented. In general, the Mission Plan states that a site shall be returned as nearly as practicable to its original condition. This became the objective of the BWIP reclamation project. Although the Hanford Site was not determined to be unsuitable for licensing, for purposes of decommissioning, the provisions spelled out in the DOE Mission Plan were applied to BWIP closeout.

\subsection{SITE HISTORY}

The Hanford Site constitules a significant preserve of natural resources in the state of Washington because of its unique history and location. This history is outlined in the following subsections.

\subsubsection{Pre-Nuclear History}

Lewis and Clark, who traveled the Columbia and Snake rivers during their 1803-1806 exploration of the Louisiana Territory, were the first Euro-Americans in the region. Fur trappers soon followed, passing through on their way to more productive lands to the west In the 1860s, merchants established stores, a freight depot, and the White Bluffs Ferry on the Hanford reach of the Columbia River. Chinese miners began to work the gravel bars for gold. In the $1880 \mathrm{~s}$, catle ranches and farms developed. In the early twentieth century, the small towns of Hanford, White Bluffs, and Ringold thrived. These towns were razed and the people relocated after the U.S. government acquired the land for nuclear materials production in the early 1940s (Cushing 1987).

\subsubsection{Nuclear (Since 1943) History}

The Hanford Site was chosen in 1943 as the location for the plutonium production facilities needed to produce an atomic bomb. Three reactors began producing plutonium in 1944-1945. Chemical separations facilities began operating in 1944, separating plutonium from the irradiated uranium fuel elements (Chatters 1989).

After World War II the reactors continued to produce plutonium. In August 1947, a major expansion was announced, including construction of six additional reactors.
In 1964 , a reduction of nuclear arms production began. By 1972 all reactors were shut down except the N Reactor, and all of the separation plants were shut down except the Plutonium-Uranium Extraction (PUREX) plant (Chatters 1989).

In the 1970s, the Washington Public Power Supply System, a not-for-profit joint operating agency of public utilities in the Pacific Northwest, began constructing three nuclear power reactors in the southeastern porion of the Hanford Site. Reactor WNP-2 has been generating electricity for commercial use since 1984. Reactors WNP-1 and WNP-4 have been mothballed (an extended construction delay) (Chatters 1989).

Today the Hanford Site is managed by DOE. The Hanford mission includes conducting research, developing new technology, managing the disposal of radioactive wastes, and conducting environmental, health, monitoring, and safety sudies. The only large-scale DOE reactor operating on the Hanford Sile is the Fast Flux Test Facility, located in the 400 Area. This sodium-cooled reactor began full-scale operations in April 1982 as a test reactor for testing reactor fuels and materials (Chatters 1989).

Because public access to the Hanford Sile has been restricted since the $1940 \mathrm{~s}$, it is the only expanse of nearly pristine shrub-steppe habitat in the state of Washington. Consequently, much of the Site is designated as wildlife refuges and ecological reserves.

\subsection{SITE DESCRIPTION}

The Hanford Sile is located in southeastem Washington Stace, occupying an area of approximately $1450 \mathrm{~km}^{2}$ (Figure 1). The Hanford Site lies within the Pasco Basin, the structural and topographic low part of the Columbia Plateau. The terrain of the basin is relatively flat with subue topographical features formed by large, glacially related floods that occured in the Pasco Basin more than 13,000 years ago. The semiarid land has sparse covering of desert shrubs and drought-resistant grasses. The most broadly distributed vegetation type on the Site is the sagebrush/cheatgrass/bluegrass community. The ESF is situated within the Cold Creek Synchine, which is a low area between the Umtanum Ridge-Gable Mountain structure and the Yakima Ridge anticline. 


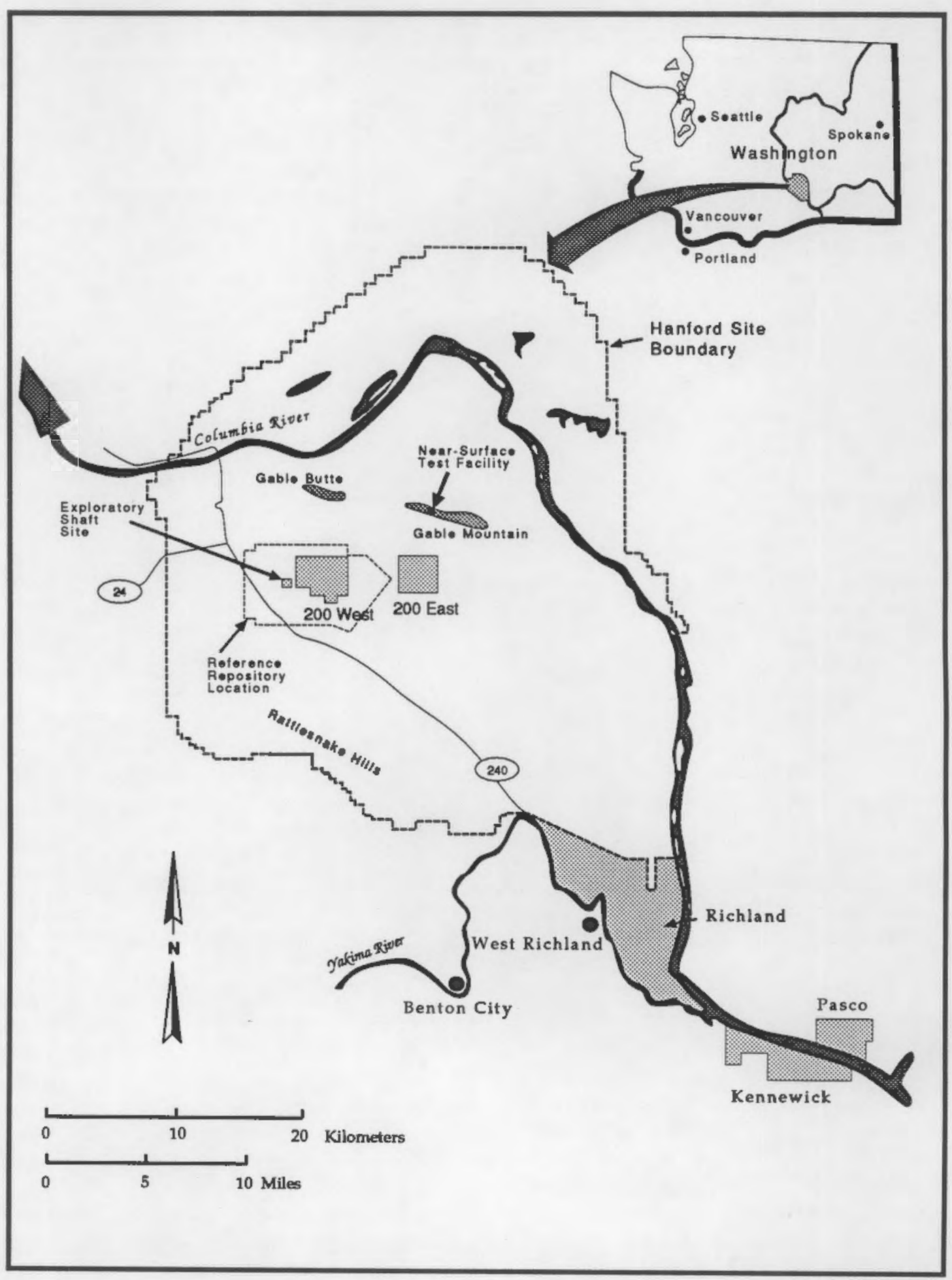

Figure 1. Location of the Reference Repository Location and the Hanford Site. 


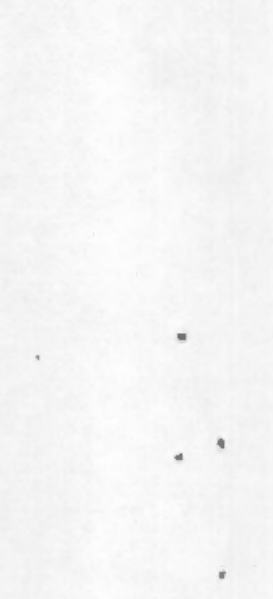




\subsection{RECLAMATION PROGRAM}

The DOE determined on the basis of commitments made in several National Environmental Policy Act (NEPA) documents that sites disturbed by BWIP would be restored to conditions similar to natural plant communities adjacent to disturbed areas unless altemative land uses were to be implemented (DOE 1978, 1982, 1986). Primary goals were to establish self-sustaining vegetation and to produce cover conditions comparable to those existing before the disturbance. Restoration focused on re-establishment of native plant species and suppression of invading exotic species. Disturbed sites located entirely within plant communities dominated by exotic species would not be required to be reclaimed with native species.

For the purpose of reclamation, natural vegetation is defined as the pre-existing vegetation of sites before BWIP disturbance and can generally be determined by the plant communities surrounding a disturbed site. Native vegetation is defined as plants endemic to southeastem Washington as opposed to exotic vegetation. Exotic or alien vegetation is defined as plants that are not native to southeastern Washington (i.e., have been imported in historic times from outside this region).

The DOE has determined that recovery of natural vegetation on disturbed sites and eventual restoration success will be evaluated for 1 year after completion of the reclamation activities and a determination will be made within that time relative to the need for additional reclamation work. Success will be based on how well the planted stands resemble nearby undisturbed plant communities.

\subsection{ENVIRONMENTAL CONSTRAINTS}

The definition of a successful reclamation program must account for a number of environmental constraints and processes that impinge on a site. The primary process involved is that of plant succession, which involves five stages: propagule migration, plant establishment, edaphic (soil) reaction, competition, and stabilization. Propagule migration can be enhanced by seeding or planting appropriate species; subsequent plant establishment may be influenced by manipulation of soil and mieroclimauic features of the site. Edaphic reaction follows, in which the biotic and abiotic characteristics of the soil are modified by growth and development of the resident plants. At some point, competition between plants will become important, changing the community structure on the site. Competition can be modified by manipulating species types, rates of interaction, and timing of interaction. Finally, succession is expected to produce a stable mix of species and edaphic characteristics.

Constraints that define the rates and endpoints of succession at any particular site include climatic factors, edaphic (soil) characteristics, competition from uative and non-native species, and seed germination and growth characteristics of the desired species. In arid areas, moisture availability and interspecific competition from alien annuals are the key constraints to reclamation.

\subsubsection{Climate}

Air temperature, precipitation, and wind are key influences that govern the geographic distribution of plants and animals on the Hanford Site. Climatological data for the Hanford Site have been gathered continuously since 1953 at the Hanford Meteorological Station (HMS), located near the 200-West Area. Although the HMS was established in 1944, data collection was not routinely established until 1953. Data for the years between 1912 and 1944 were recorded at the Hanford Townsite near the Columbia River.

High temperatures average in excess of $32^{\circ} \mathrm{C}$ during July and August, with a record high of $46^{\circ} \mathrm{C}$ in July 1939 (Figure 2). Winter (November to February) minimum temperatures average between $-7^{\circ} \mathrm{C}$ and $-1^{\circ} \mathrm{C}$, with a record low of $-33^{\circ} \mathrm{C}$ (in December 1919).

Annual precipitation has exhibited a fairly broad range of variability since 1912 (Figure 3). The driest year on record was 1976, with a total precipitation of $7.5 \mathrm{~cm}$, or $47 \%$ of normal. The wettest years were 1940 and 1950 , with 28.2 and $28.6 \mathrm{~cm}$, respectively. Annual precipitation may be expected to fall between 12.5 and $20 \mathrm{~cm}$, though nearly $20 \%$ of the years between 1912 and 1987 experienced less than $12.5 \mathrm{~cm}$ (Figure 4). 


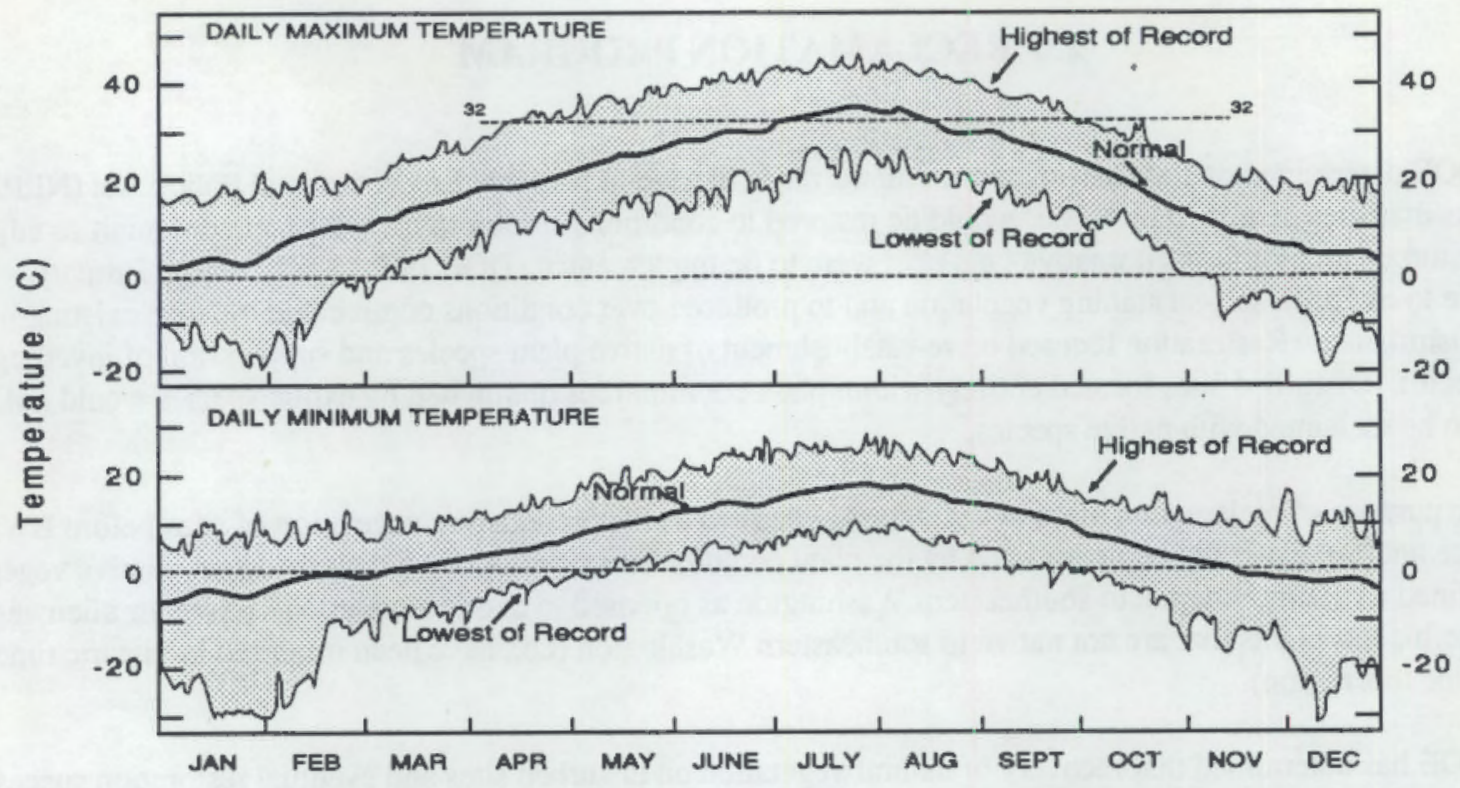

Figure 2. Normal and Extreme Daily Temperatures at Hanford

On average, some $52 \%$ of annual precipitation falls from November to February (Figure 5). Monthly precipitation rates decline from the December high of 2.3 $\mathrm{cm}$, but increase again from April to a secondary maximum in June of $1.3 \mathrm{~cm}$. July is the driest month, with an average of only $0.4 \mathrm{~cm}$ of precipitation. The year may thus be subdivided into three phases, based on temperature and precipitation regimes: 1) a dry, hot season from July through October, 2) a relatively wetter cool season from November and February, and 3) a dry, warm season from March to June (Figure 6).

The November through February period is most important in terms of input to soil moisture. This 4-month period experiences an average of $8.5 \mathrm{~cm}$ of rainfall and a mean temperature of $1.4 \mathrm{C}$. At least some rain has occurred during this period in every year since 1912 (Figure 7). Thirty-three percent of all

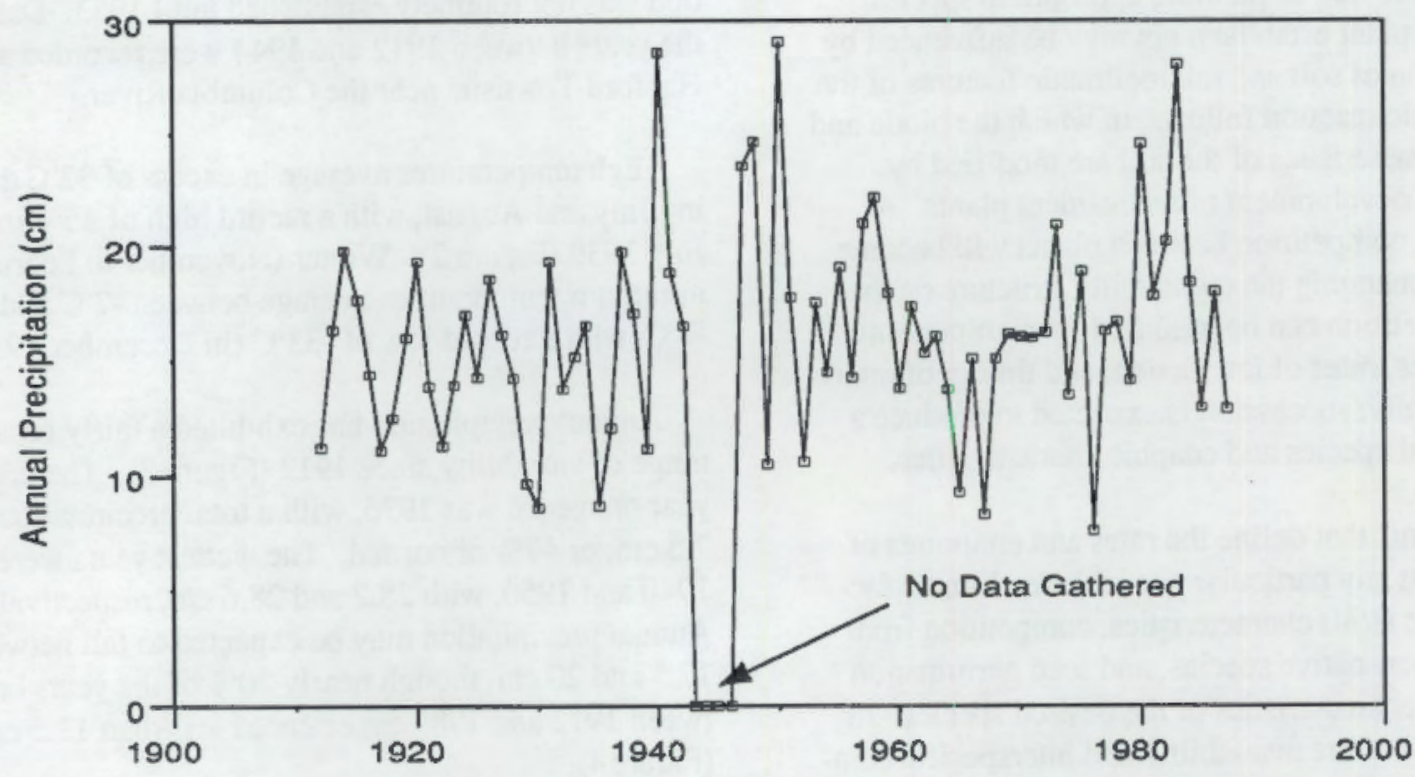

Figure 3. Annual Precipitation at Hanford Since 1912 


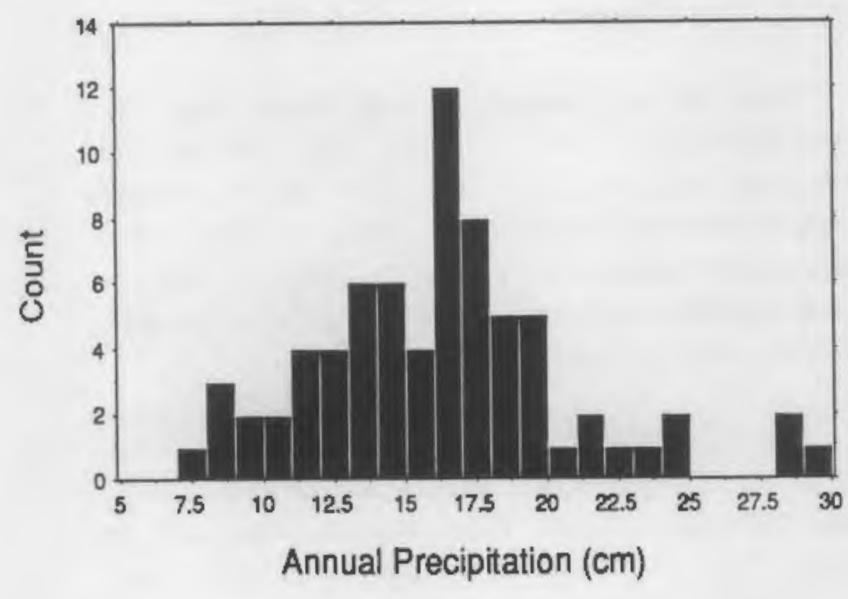

Figure 4. Hislogram of Annual Precipitation at Hanford, 1912 - 1987

years since 1912 had between 7.5 and $9.5 \mathrm{~cm}$ of rainfall in these months. Rainfall during this period ranged from a low of $2.2 \mathrm{~cm}$ to a high of $17.5 \mathrm{~cm}$. Together with the low temperatures and high relative humidity ( 70 to $80 \%$ ) during this period, evapotranspiration losses are minimal. Most of the precipitation remains in the topsoil, except when Chinook winds or warm rains occur after a period of subfreezing temperatures. In such cases, much of the precipitation and melting snow may run off.

The period from March to June represents a transition from the relatively wet, cool winter to the hot,

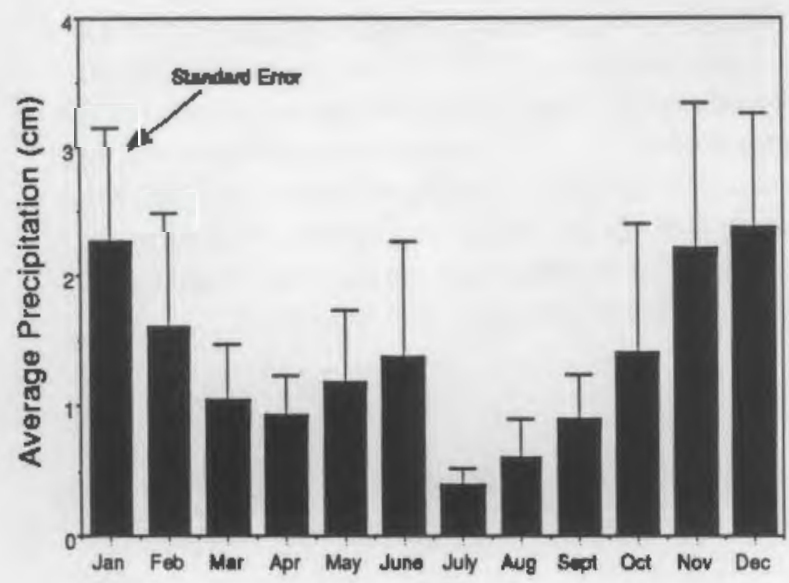

Figure 5. Average Monthly Precipitation at Hanford, 1912 - 1987 very dry summer and early fall. Temperatures during this transition period average $14^{\circ} \mathrm{C}$, and precipitation averages $4.5 \mathrm{~cm}$ (Figures 6 and 7). Precipitation ranges from a low of $0.62 \mathrm{~cm}$ to a maximum of 11.2 $\mathrm{cm}$, with most of this occurring in the month of June. Thirty-four percent of years since 1912 received between 1.1 and $4.2 \mathrm{~cm}$.

The dry season occurs from July through October, a period especially stressful for plant survival. These months include the hottest and driest of the year; only rarely are winter and spring moisture accumulations sufficient to provide a carry-over of available soil moisture through this period (Hinds and Thorp 1972).

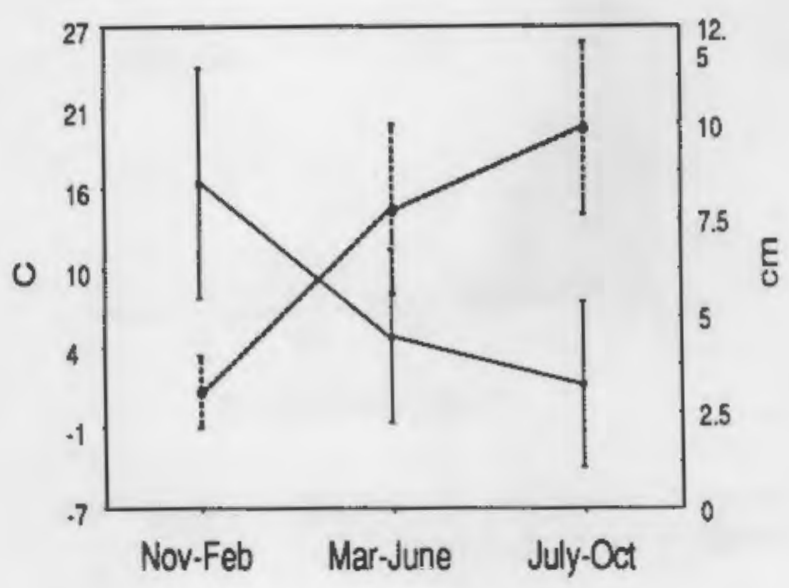

Figure 6. Average Temperature (broken line) and Precipitation (solid line) for Three Periods of the Year

Temperatures average $19.7^{\circ} \mathrm{C}$, and rainfall averages $3.2 \mathrm{~cm}$ (Figures 6 and 7). Precipitation during this period ranges from a low of $0.17 \mathrm{~cm}$ to a high of 12.2 $\mathrm{cm}$, most of which falls during summer thunderstorms (Stone et al. 1983). The extreme dryness of this period is reflected in the fact that $75 \%$ of all years since 1912 had less than $4.2 \mathrm{~cm}$ of rainfall during this 4-month period.

The key implication of these data for revegetation is that the ESF lies in an arid zone that experiences a net input to soil moisture between November and February and a severe moisture deficit from July to October. Summer storms occasionally drop large amounts of moisture, but these are very infrequent and 


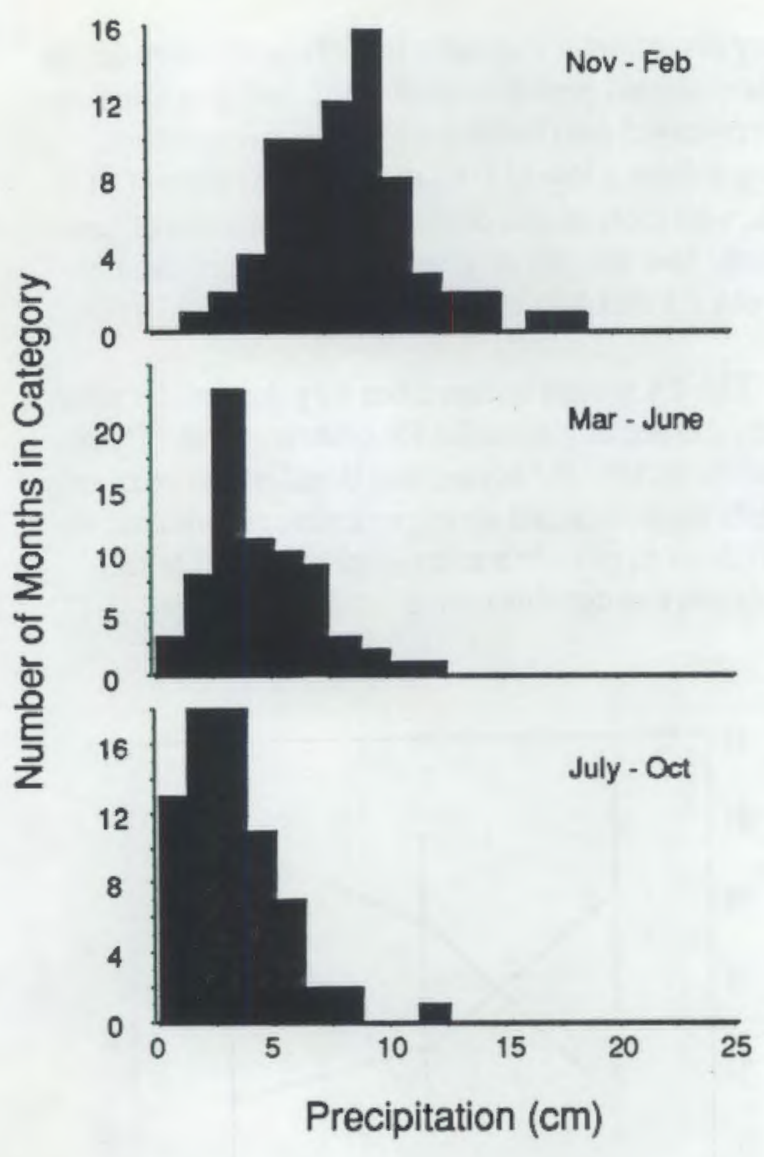

Figure 7. Histograms of Precipitation During Three Periods of the Year, 1912 - 1987

cannot be relied on to sustain plant growth. Precipitation during any period is unreliable: droughts have $\propto$ curred in 1 of 5 years. Temperatures during the winter months are usually not so low as to preclude some plant growth at that time: indeed most of the shrubs and grasses are physiologically very active during this period. However, arctic air masses occasionally push the temperatures down to $-20^{\circ} \mathrm{C}$ or $-30^{\circ} \mathrm{C}$. At these temperatures, damage to unprotected growing plants may be severe. The transition period between March and June may be of primary importance to plant establishment. Temperatures improve greatly from the winter lows, and moisture inputs usually increase. Again, however, $15 \%$ of years since 1912 have failed to receive $2.5 \mathrm{~cm}$ of precipitation during this period. Thus, providing adequate moisture to revegetated plants will be a critical to their success, at least during the first growth year. Options include irrigation and microtopographic modifications and planting schemes that will enhance snow harvesting and modify the soil moisture profile

\subsubsection{Wind Regimes}

Wind data are routinely collected at the HMS. In addition to the surface $(7-\mathrm{ft})$ wind data, wind data are collected at the 50-, 100-, 200-, 300-, and 400-ft intervals of the 410-ft tower at the HMS. Telemetry stations distributed on and around the Hanford Site provide supplementary surface (30-ft) wind data for defining wind patterns.

Prevailing wind directions are from the northwest in all months (Figure 8). Southwesterly winds are of secondary importance. Wind direction summaries indicate that winds from the northwest quadrant occur most often during the winter (December through February) and summer (June through August). During the spring and fall, the frequency of southwesterly winds increases with a corresponding decrease in northwesterly flow. Winds blowing from other directions (e.g., northeast) display minimal variation from month to month.

Monthly average wind speeds are lowest during the winter months, averaging 9 to $11 \mathrm{~km}$ per hour, and highest during the summer, averaging 14 to $16 \mathrm{~km}$ per hour. Wind speeds that are well above average are usually associated with southwesterly winds. In the summer, high-speed winds from the southwest are responsible for most of the dust storms experienced in the region.

Wind and precipitation regimes combine to make the summer months the critical period when erosion potential is at its highest. Winds at the ESF during this period will generally be from the west to northwest. Because of the great size of the disturbed area at the ESF and the types of soils present (see next section), erosion control measures are necessary to prevent disruption of the soil-root contact for secded plants. Erosion control measures that have been employed at the site include the use of tacking agents, incorporating mulches such as straw into the soil, mechanical compaction of the soil surface, and irrigation.

\subsubsection{Soils}

Soils are classified according to general type, such as the Ritzville or Warden series, and subdivided according to texture. Soil series are named for towns or other geographic features near the place where soils of that series were first described (Rasmussen 1971). Further characterization of soils reflects differences in 


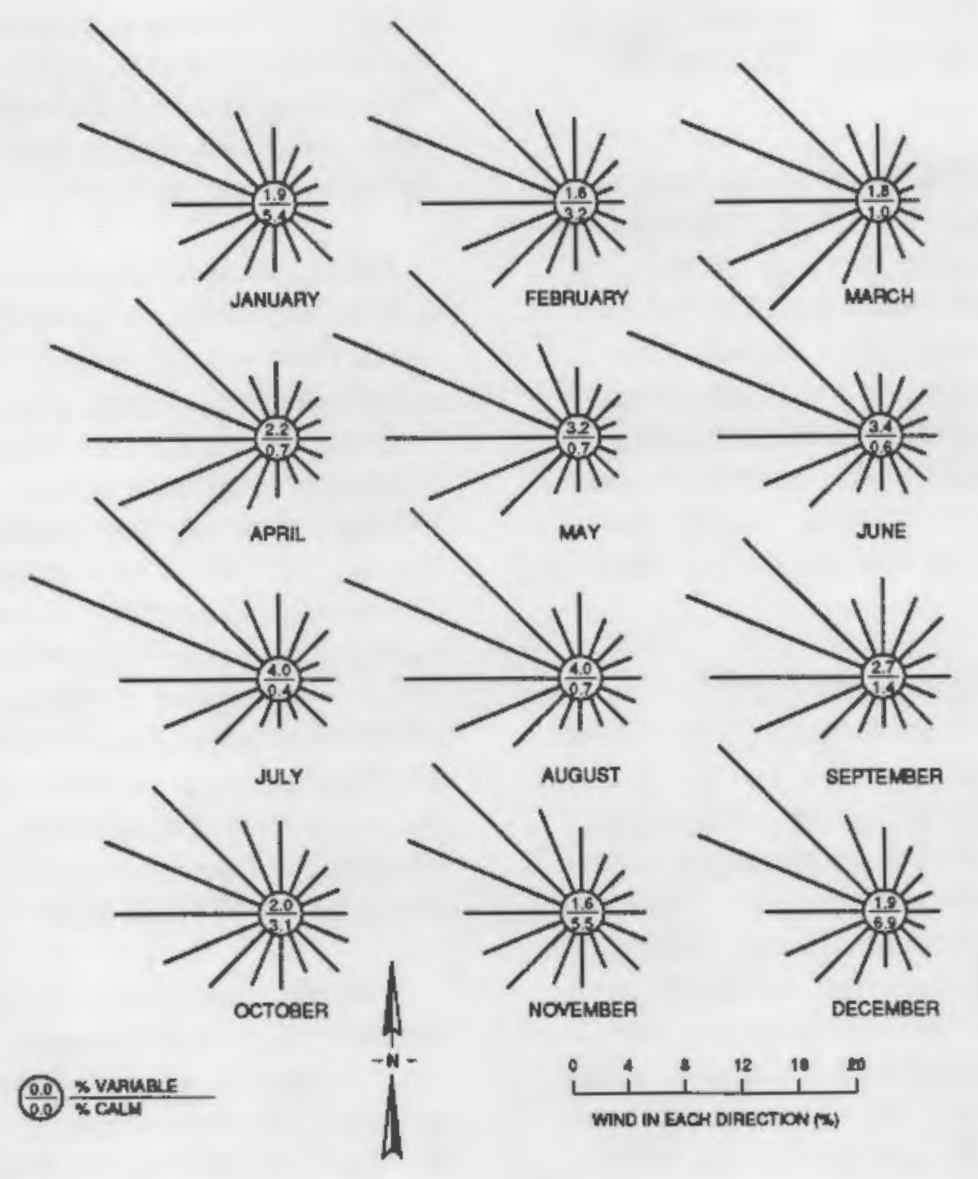

Figure 8. Monthly Wind Roses for the HMS Based on 50-ft Wind Data, 1955 - 1980

vegetative history, soil depth, parent material, and nature of deposition.

The boundaries of plant communities and soil types do not necessarily coincide (Daubenmire 1970). However, soil characteristics important to plants on the Hanford Site include water holding capacity, depth, and parent material. Water-holding capacity is a function of texture and organic content: fine-textured soils, such as silt loams, have higher water-holding capacities than sands (Bradshaw and Chadwick 1980). The soil of the ESF is mapped as Hezel Sand, characterized as a sandy loam having greater than $50 \%$ of its structure composed of sand. Water-holding capacity is thus expected to be low.

\subsubsection{Plant Communities}

The Hanford Site lies within the shrub-steppe ecosystem, which is characterized by desert shrubs [e.g., sagebrush (Artemisia Spp.), rabbitbrush (Chrysothamnus spp.), and bitterbrush (Purshia tridentata)] and bunchgrasses [e.g., bluegrasses (Poa spp.) and wheatgrasses (Agropyron spp.)] in roughly equal proportions, at least under pristine conditions (Daubenmire 1970).

Native plants important to revegetation of the ESF are comprised mainly of cool-season species (Rickard 1988). Vegetative growth occurs primarily during the late fall after the first rains and during spring before the extreme temperatures of summer (Rickard and Schuler 1988). The primary shrub species, big sagebrush (Artemisia tridentata), is capable of photosynthesis year-round, provided sufficient water is present in the soil and air temperatures are between $10^{\circ} \mathrm{C}$ and $20^{\circ} \mathrm{C}$ (DePuit and Caldwell 1973). Usually, however, growth is greatest in the cool season. Flowering and seed set occur in late November to early December. Germination of big sagebrush seeds is inhibited by 
continuous temperatures below $5^{\circ} \mathrm{C}$, and highest when warm-period temperatures reach $15^{\circ} \mathrm{C}$ (Evans and Young 1986).

The most problematic shrub species as far as revegetation of the ESF is concerned is spiny hopsage (Atriplex spinosa). Spiny hopsage drops its leaves at the onset of hot weather and remains dormant until late winter (Rickard and Schuler 1988). Its peak growth period is thus limited to the cool, moist conditions of the spring. Spiny hopsage flowers in early spring and sets seed just before leaf-drop. Germination of seeds under laboratory conditions reached optimum levels when exposed to $5^{\circ} \mathrm{C}$ nights and $10^{\circ} \mathrm{C}$ to $30^{\circ} \mathrm{C}$ days (Wood et al. 1976).

The principal native grasses important to revegetation of the ESF are Sandberg bluegrass (Poa sandbergii), bottlebrush squirreltail (Sitanion hystrix), and needle-and-thread grass (Stipa comata). Cheatgrass (Bromus tectorum) is an important non-native component of most habitats on the Hanford Site. Cheatgrass, an annual, is a highly competitive species, especially on disturbed areas. Both cheatgrass and Sandberg bluegrass germinate after the first significant rains in fall. Sandberg bluegrass sets seed during early spring, then becomes dormant until fall. Cheatgrass sets seed slightly later, then dies (Rickard and Schuler 1988). Sandberg bluegrass seeds have low germinability until 6 months after dehiscence (Evans et al. 1977).

Germination of Sandberg bluegrass seeds is highest at daytime temperatures of $15^{\circ} \mathrm{C}$ to $25^{\circ} \mathrm{C}$ and overnight temperatures of $5^{\circ} \mathrm{C}$ to $15^{\circ} \mathrm{C}$ (Evans et al. 1977). Needle-and-thread grass seeds germinate in early winter (Rickard and Schuler 1988); bottlebrush squirreltail germinates in late fall and early winter (Young and Evans 1977). Bottlebrush squirreltail seed germination is highest under conditions of warm days $\left(10^{\circ} \mathrm{C}\right.$ to $20^{\circ} \mathrm{C}$ ) and cool nights $\left(5^{\circ} \mathrm{C}\right)$, but, like all the grasses, may be inhibited by low soil moisture (Young and Evans 1977).

A number of alien annual species occur on the Hanford Site. Most of these are early successional varieties that rapidly colonize areas of soil disturbance. Such colonizers include prickly lettuce (Lactuca serriola), tansy mustard (Descurainea pinnata), tumble mustard (Sisymbrium altissimum), Russian thistle (Salsola kali), and cheatgrass (Bromus tectorum). The most aggressive and ubiquitous of these is cheatgrass. Areas occupied by cheatgrass are resistant to invasion by native species (Rickard and Sauer 1982).

Cheatgrass is a Eurasian native that was introduced to Washington State in the 1890s (Klemmedson and Smith 1964, in Daubenmire 1970). The first plants to colonize a disrupted (e.g., plowed) area are usually Russian thistle and tumble mustard, though these are completely eliminated in a few years by cheatgrass without appropriate management (Daubenmire 1970). In arid areas such as the Hanford Site, cheatgrass occurs in nearly pure stands on formerly disturbed ground. Old fields abandoned on the Site in the early 1940 s continue to be dominated by cheatgrass, to the exclusion of native species (Rickard and Vaughan 1989). Other areas outside the Hanford Site have remained as nearly pure stands of cheatgrass despite the elimination of human-caused disturbances at least as far back as 1911 (Daubenmire 1970).

Two considerations for reclamation derived from the above discussion are significant for revegetating the ESF site with native vegetation. First, the native grasses all germinate during the early fall period after the first significant rains, a period when soil temperatures are still high but occasional freezing air temperatures may be expected. Because native grasses are cool-season species, they perform most of their growth and nutrient storage during the winter before the ground freezes and in the spring between ground-thaw and summer heat (Chapin 1980). Grasses planted too close in time to ground freeze or in the spring may not have sufficient time to establish an adequate nutrient and moisture base to carry them successfully through summer dormancy. Irrigation may enhance the rate of survival should planting be performed late, but if dormancy is triggered by day length or temperature, such actions will be futile.

The second consideration for reclamation deals with competition from cheatgrass. As a component of nearly all communities on the Hanford Site, cheatgrass can be expected to invade the ESF site at some point. Establishment of native grasses early in the successional cycle prior to that invasion is essential to their continued presence at that site (Daubenmire 1970). 


\subsection{DERIVATION OF RECOMMENDATION FOR RECLAMATION}

A specific reclamation objective was formulated for the ESF and associated boreholes RRL-2B and C based on pertinent regulations; commitments made by DOE; considerations for the interests of Native Americans as interpreted by the DOE; lechnical issues regarding the climate, soil, and plant communities of the ESF area; specific details of the nature of the disturbance at the site; and information collected from onsite and elsewhere regarding revegetation practice in arid environments. The reclamation objective was to restore the site to conditions present in the undisturbed community surrounding the site.

\subsubsection{Identification of Existing Site Conditions}

The ESF was visited in April 1988 by Pacific Northwest Laboratory (PNL) reclamation staff to determine the nature of the disturbance and the status of the surrounding habitat, to compare soil parameters in disturbed and undisturbed areas, and to identify the primary stumbling blocks for revegetation.

Westinghouse Hanford Company personnel were consulted to identify the intended use of the site and any decommissioning constraints that might affect site reclamation. It was determined that borehole RRL-2C was to be retained as part of the Hanford ground-water monitoring network, otherwise all areas were to be returned to original conditions.

At the time of the review, the ESF was occupied by 13 mobile office trailers, a large rotary rig and associated shop, compressors, crew trailer, mud mixing tank, and 17 sections of 112 -in. I.D. steel well casing (Figure 9). The drill rig was mounted on a reinforced concrete foundation over a 156-in. diameler starter hole dug and lined to $100 \mathrm{ft}$ depth with corrugated metal pipe. The top $17 \mathrm{ft}$ of the starter hole were supported with a reinforced concrete collar. A large mud pit was excavated south of the drill rig and equipped with steel piling baffles. Drilling mud had been mixed in this pit in preparation for drilling the main shaft.

The sile was enclosed by a chain link fence with two vehicle gates and one pedestrian gate. An asphalt roadway provided access to the south vehicle gate, and a dirt road paralleled the fence outside on the west. Both the ESF and the two well sites were covered by approximately 12 in. of compacted rock/gravel/sand mixture. Electrical power, water and sewage lines, and communication utilities were all buried. A septic tank and drain field served the offices. A positive displacement sucker rod pump occupied the pad on borehole RRL-2B. This pump was connected via aluminum pipe to a bermed pit west of the pad. A dirt road connected the pad at borehole RRL-2B to the bermed pit.

During demolition, all equipment, buildings, utilities, roadways, and gravels will be removed. However, two constraints were identified that affect site restoration: the reinforced concrete collar supporting the rotary drill rig would be too expensive to remove and, therefore, must be disposed of in place. Also, there was insufficient soil present to build a mound of soil over the collar and fill the large mud pit south of the drill rig.

\subsubsection{Revegetation Methods and Materials}

The ESF was revisited in April and May 1988 to characterize the nearby undisturbed community and to determine what, if any, residual toxicity remained in the soils from prior herbicide applications. These data were used to design revegetation specifications for the site.

The vegetative community was assessed in relatively undisturbed areas representing the least disturbed native community near the site. On May 11-13, 1988, four plots were located at the site: one west of RRL-2B, one north of the ESF, and two west of the ESF. No plot was located at borehole RRL-2C because the only undisturbed habitat at that site lay some distance inside the 200-West Area fence. The community at borehole RRL-2C was assumed to be adequately represented by the samples taken at the four plots across Army Loop Road. Sampling locations consisted of $10-\times 10-\mathrm{m}$ plots located at least $10 \mathrm{~m}$ from the edge of the reclamation site. Plots were marked with wooden stakes bearing the site and location designations. Canopy cover of grasses and shrubs was measured along the side of the plot nearest the disturbed area. Plant cover was measured using the point-interception method (Goodall 1953) by means of an optical point bar (Viert 1985). The bar consists of 10 ocular scopes with crosshairs. Species were recorded whenever they intersected the view beyond the crosshairs. Sampling using the optical point bar was repeated at 1-in intervals starting $1 \mathrm{~m}$ from one corner of the plot. Percent cover for any species at any sampling location was therefore simply the sum of the point interceptions for that species at that location. 


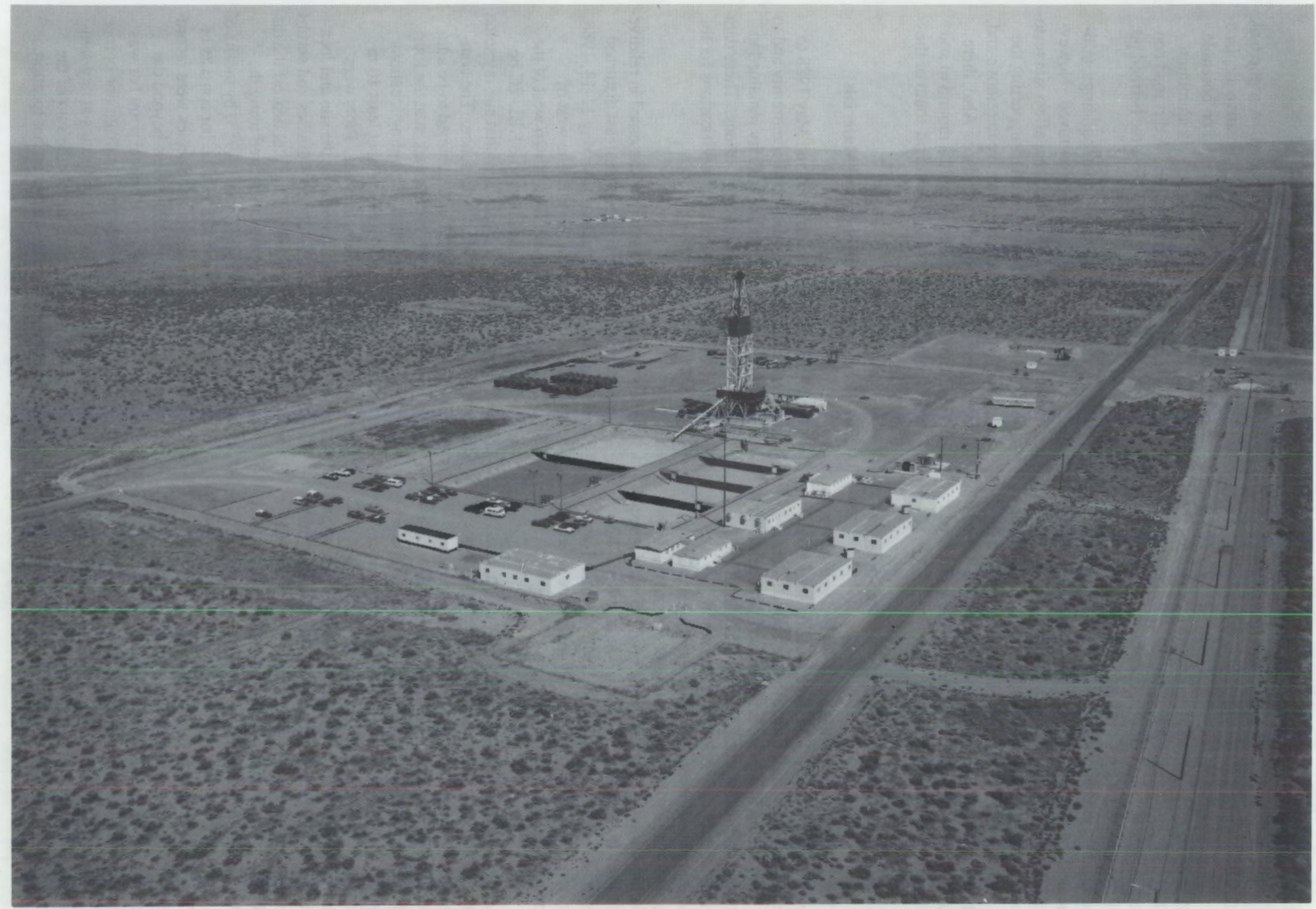

Figure 9. Aerial Photograph of the Exploratory Shaft Facility as Constructed 
Shrub density was determined by counting all shrubs, by species, within the plot. Finally, all species present within the plot were tallied. Plots were sampled again on June 21,1988. During the time since the previous sampling, the stakes marking the plot at borehole RRL-2B had been removed and the original plot could not be relocated. Consequently, a fifth plot was added south of the ESF.

The ESF and boreholes RRL-2B and C are surrounded by a big sagebrush-cheatgrass community. Overstory was dominated by big sagebrush at two of the five sampling plots, but grey rabbitbrush (Chrysothamnus nauseosus) predominated in the remaining three sites. Other shrub components include green rabbitbrush (C. viscidiflorus) and spiny hopsage (Table 1). Cheatgrass dominated the understory in every plot, though Sandberg bluegrass, botulebrush squirreltail, and needle-and-thread were also present. Complete data are presented in Appendix A.

Soil samples were collected on April 15, 1988, to determine the physical and chemical characteristics of undisturbed soils near the borehole sites. Samples were taken at $15-\mathrm{cm}$ depth at four locations around the perimeters of the ESF and borehole RRL-2B. Samples were composited for analysis. Parameters analyzed were texture (percent sand, silt, and clay), $\mathrm{pH}$, phosphorus, potassium, total Kjeldahl nitrogen, organic carbon, and cation exchange capacity. Data are presented in Table 2.

Table 1. Average Cover and/or Plant Density for Species in Undisturbed Plots Located Outside the ESF and Borehole RRL-2B. $N=5$ plots. Data for three plots are average values taken from tow dates of measurement (Appendix A).

\begin{tabular}{l} 
Species \\
\hline Cheatgrass \\
Sandberg bluegrass \\
Needle-and-thread grass \\
Bigsagebrush \\
Grey rabbitbrush \\
Green rabbilbrush \\
Spiny hopsage
\end{tabular}

\begin{tabular}{|c|c|}
\hline \multicolumn{2}{|c|}{ Percent Cover } \\
\hline Mean & Sud. Dev. \\
\hline 41 & 14.8 \\
\hline 02 & 0.3 \\
\hline 0.1 & 0.2 \\
\hline 8.1 & 7.3 \\
\hline 6 & 5.9 \\
\hline 1 & 22 \\
\hline 0 & 0 \\
\hline
\end{tabular}

\begin{tabular}{cc}
\multicolumn{2}{c}{ Shrub Density (\#/0.01 ha) } \\
\hline Mean & Std.Dev. \\
\cline { 3 - 3 } N/A & N/A \\
N/A & N/A \\
N/A & N/A \\
11.8 & 9.5 \\
84.7 & 123.3 \\
2.7 & 43 \\
0.2 & 0.35
\end{tabular}

Table 2. Soil Parameters from Undisturbed Soils Surrounding the ESF

\begin{tabular}{|c|c|c|c|c|c|c|c|c|c|}
\hline Location & $\mathrm{Pn}_{\mathrm{n}}$ & $\begin{array}{c}P \\
\text { (gam) }\end{array}$ & $\underset{\text { (ppen) }}{K}$ & $\begin{array}{c}\mathbf{N} \\
\text { (ष्) }\end{array}$ & $\begin{array}{c}\text { Organic } \\
\mathrm{C}(\%)\end{array}$ & $\begin{array}{c}\text { CEC } \\
(\mathrm{meq} / 100 \mathrm{~g})\end{array}$ & $\begin{array}{l}\text { Send } \\
\text { (\%) }\end{array}$ & Silt & $\begin{array}{l}\text { Cry } \\
(\%)\end{array}$ \\
\hline $\begin{array}{l}\text { ESF and RRL-2B } \\
\text { Perimeter }\end{array}$ & 76 & 10.6 & 269 & 0.02 & 0.16 & 5.4 & 88.9 & 7.1 & 3.9 \\
\hline
\end{tabular}





\subsection{RECLAMATION METHODS}

In formulating reclamation recommendations, our considerations were in order of priority:

- the objective stated in the reclamation plans: returning sites as near as possible to native plant communities

- the time frame available in which to accomplish that objective: 2 years

- the technical factors that would prevent obtaining that objective

- how to approach the objective at a reasonable cost.

Technical constraints and considerations for the ESF and boreholes RRL-2B and C and the means selected to overcome or minimize each constraint are identified in Table 3. The overall framework for developing the reclamation program is given in Figure 10.

\subsection{DEMOLITION PHASE}

The contents of the large mud pits at the ESF and borehole RRL-2B were examined to determine if any would require disposition according to the Resource Conservation and Recovery Act (RCRA), the Washington Solid Waste Management Act, or the Washington Hazardous Waste Management Act. No hazardous materials were identified.
Aboveground facilities including trailers, the rotary drill rig, drilling equipment, well casings, valves, meters, office and power supplies, fencing, and portable equipment were removed and salvaged. Utilities buried within $90 \mathrm{~cm}$ of the natural ground surface were uncovered and removed. Permanent below-ground sanitary facilities were removed and holes backfilled. Asphalt roadways and walkways were removed and hauled to the landfill.

Table 3. Site-specific Constraints and Considerations and Their Solutions to be Implemented in the Reclamation Program.

\section{Sile Consunins}

An artificil mound covering the drill rig collhr will be composed of gravels and sand with low nutrients and organic matter.

Constant soil moisture during early growh is critical to planting success.

Chentgrass is a dominmt element of the vegetation surrounding the site.

Previous nuempts at establishing big sagebrush from seed elvewhere on the Henford Site had met with little success.

Spiny hopsage plants on the Hanford Site all belong wo very old age class, indicating successful reproduction from seed has been rare.

Site will be cleared of top course materials several months before seeding.

\section{Site Solution}

Slow-release nirrogen fentilizer (sulphur-conted urea) will be added at the rate of $34 \mathrm{~kg} \mathrm{~N} / \mathrm{ha}$ to site prior to cultivation of seedbed.

Irrigation water will be available at the site after reclamation is cornpleted; therefore, the sile will be irrigated sufficient to generave $2.5 \mathrm{~cm}$ of moisture per month, including rainfall, from March w June 1989 after seeding is completed.

Site will be cleared of gravel after cheargrass has set seed, and will be seeded with native speciea before growth of next generation of cheatgrass.

Seed of more-easily generated shrub species will be used with supplemenul irrigation. This uctic increases the risk of failure to establish shrubs, vs. using tubeling stock

Spiny hopsage will be established from containerized (tubeling) stock.

Site surface will be proxected from wind erosion by application of an organic lacking agent. 
Original conditions: Wildife habitat Industrial use

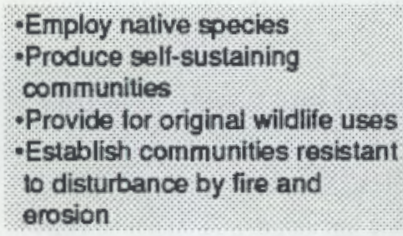

Grasses: Drilling during Sept 15 to Oct 15 most successful on Hanford site

Shrubs: Seeding attempts on Hantord had no success; tubelings planted during high-moisture period likely to have grealest success

\section{Decision on future land use}

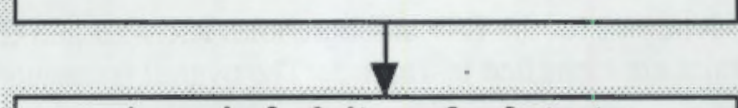

Appraisal of site and substrate (climate, physical properties, fertility, toxicity, etc.)

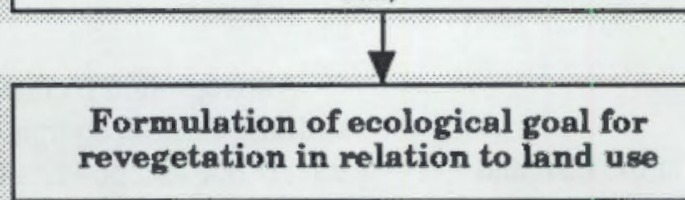
revegetation in relation to land use
Development of amelioration program (fertilizer, organic mulches, tacking agents, topsoil addition, cation exchange capacity, contouring, microclimate alteration)

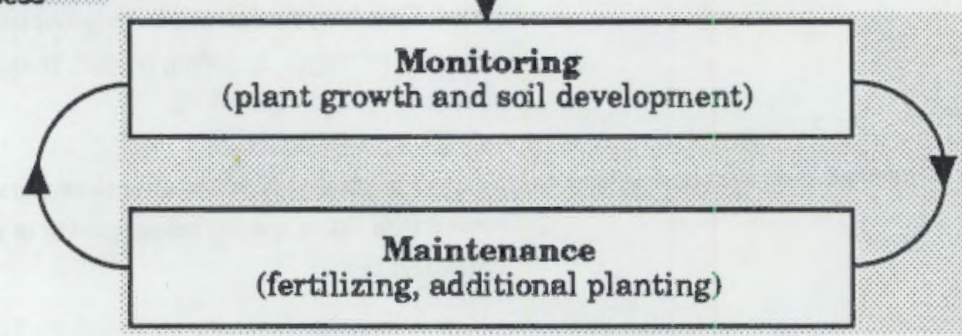

Development of seeding/planting mixtures (grasses, legumes, other herbs; tree and shrub seeds or plantings; microbial inocula)
.6 .5 in annual rainfall - Summer temp $>90^{\circ}$ L Low soil cation exchange - Compacted solis Low organic content in soils Low nitrogen content in soils - Unnatural contours -Erodible soil surface Wildifres occasional -Non-native species present - Native recolonization slow

1) Identify community types

2) Measure cover of grasses and shrubs

3) Formulate grass seed mixtures specific to community

4) Use shrub tubelings to enhance success/cost ratio

5) Shrub density to be planted $=1.3 \times$ shrub density in community

6) Include food planis of Native Americans for NSTF

7) Use VAM inocula to lower effects of nutrient/water stress

Primary considerations are:

-2 year schedule

- Unprodiclable moisture

- Little site-specific data on revegetation with native species

Figure 10. Framework for Reclamation Decisions at the ESF 
Piling baffles were cut from the mud pits, which were then backfilled with soils salvaged from their original construction. The ESF starter hole was backfilled with base course material removed from the access roadway. Base course material throughout the site was removed down to the original soil surface. Part of this material was retained to build up a mound over the former ESF starter hole collar. The remainder was trucked to Pit 25 for disposal. Exposed soils were ripped to a depth of $30 \mathrm{~cm}$ to relieve compaction and recontoured to approximate the contours prior to construction of the ESF. A commercial organic tacking agent (J-Tac-HS) was applied to the site at a rate of $90 \mathrm{~kg} / \mathrm{ha}$. Wood cellulose fiber was incorporated with the tacking agent as a tracer. The recommended rate was $112 \mathrm{~kg} / \mathrm{ha}$; because of an oversight, the rate actually applied was $560 \mathrm{~kg} / \mathrm{ha}$. The effect of the excessive wood fiber added to the site would be to decrease the amount of soil nitrogen available to the plants (Bradshaw and Chadwick 1980). This effect was mitigated by the later addition of a slow-release nitrogen fertilizer (see Section 3.2.1).

\subsection{REVEGETATION PHASE}

Numerous studies of succession in disturbed arid regions have shown that recovery after severe disturbance, such as topsoil removal or high-temperature wildfires, will be delayed by anywhere from 6 to 50 years or more, depending on the type and extent of the disturbance (e.g., Allen 1988). Often, especially in the presence of cheatgrass, the final community type may be much different than that present before the disturbance (Biondini et al. 1985). Intervention in the form of appropriate seedbed preparation and seeding or planting appropriate vegetation will dramatically increase the probability of re-establishing a community similar to that existing before the disturbance (DePuit and Redente 1988), as illustrated in Figure 11.

The strategy employed at the ESF was to introduce as many species as possible from seed, supplement rainfall by irrigation, and establish spiny hopsage by planting tubeling stock. Revegetation of the ESF and

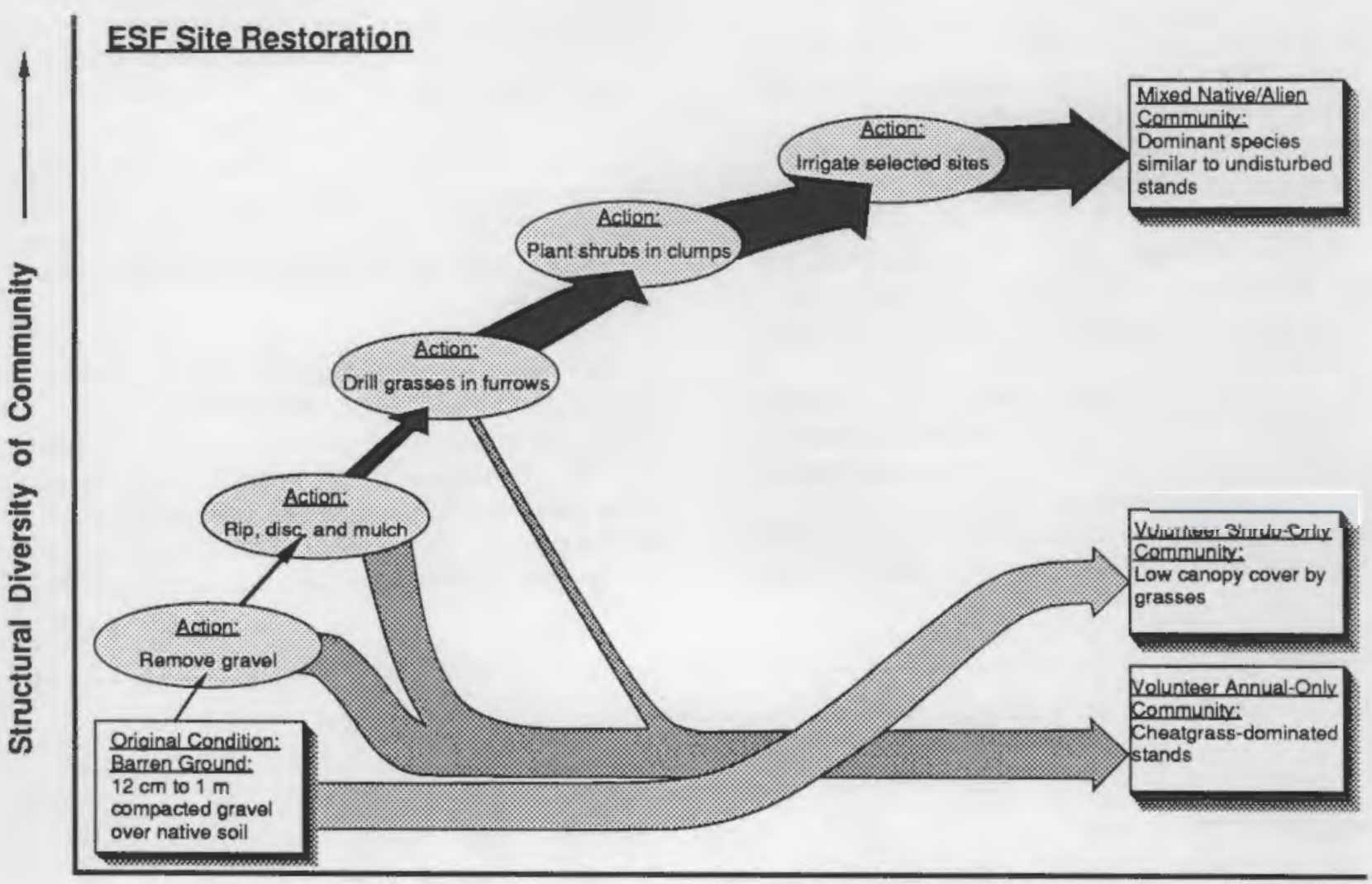

Time

Figure 11. Schematic Diagram of Community Time-Transition Trajectories at the ESF (width of transition arrows corresponds to the probability of continuing along a transition trajectory from one community type to another.) 
boreholes RRL-2B and C was to begin by September 15,1988 , with seeding completed by October 15 , 1988. Delays experienced in obtaining a revegetation contractor, however, resulted in no work being done until November. Because of this delay, seeded plants can be expected to be smaller and less hardy than plants seeded at the appropriate time (see Section 2.1.4). Irrigation during the spring growth phase (Section 3.2.5) may mitigate the effect of the delay. Revegetation consisted of five activities: seedbed preparation, seeding of grasses and shrubs, mulching with straw, planting hopsage tubelings, and irrigation.

\subsubsection{Seedbed Preparation}

Soil compaction was relieved by disking to a depth of $15 \mathrm{~cm}$. Scarification by means of disking to a depth of $15 \mathrm{~cm}$ is recommended in shallowly compacted soils (e.g., Redente et al. 1984), such as those expected to underlie the compacted base-course material at the ESF. Such treatment significantly enhances the likelihood of establishing appropriate vegetation (Biondini et al. 1985). Following disking, the seedbed was surface-compacted using a cultipacker and roller. This aids in the prevention of wind and water erosion (Toy and Shay 1987) and provides a stable base for drilling seeds to the appropriate depths (Haferkamp et al. 1987). Seedbed preparation began November 8 and was completed by November 12, 1988.

Soil samples were collected on July 12, 1988, from three strata on the reclamation area at the ESF: the mound over the former drill rig collar, the soils filling the former mud pit, and the native soils revealed by the removal of the top-course material (Table 4). Generally, soils exposed after removal of the surface course materials were higher in silt and lower in sand particles than were undisturbed soils. Organic carbon levels were slightly lower on the disturbed soils, as were levels of most macronutrients. However, no differences were large enough to warrant mitigation. Nitrogen levels on the revealed soils were similar to those in undisturbed soils (Table 2), but levels on the mound and in the mud pit area were half that on undisturbed soils. Organic matter incorporated into arid soils, and especially soils low in microbial activity, such as would be expected on the mound, will serve to bind nitrogen in forms unavailable to plants (Bradshaw and Chadwick 1980). Consequently, the application of a nitrogen fertilizer is generally recommended when carbon:nitrogen ratios exceed 20:1 (Smith et al. 1987). Carbon:nitrogen ratios on the seedbed ranged from 7:1 to 14:1. However, because of the excessive amount of wood fiber applied to the area prior to seedbed preparation and the amount of straw mulch to be applied after seeding, a slow-release nitrogen fertilizer (sulphur-coated urea) was broadcast over the reclamation areas at a rate of $34 \mathrm{~kg}$ nitrogen per hectare before seeding.

\subsubsection{Seeding}

Seeding began November 14 and was completed November 16, 1988, under cool, rainy conditions. Seeding consisted first of broadcasting seeds of Chrysothamnus spp. and Artemisia tridentata at the rate specified in Table 5. Grass seed was then drilled into the seedbed using a Truax drill calibrated to deliver seed at the rate specified in Table 6. Each grass species was drilled into alternate drill furrows by loading each species into a separate seed-hopper. Soil openers were spaced at $30 \mathrm{~cm}$. Specifications for seed are listed in Table 6.

Shrub seeds were broadcast rather than drilled because a) shrub seeds are too light and fuzzy to pass through the seed meter on the drill in a constant fashion and $b$ ) the seedling shrubs would find the areas between grass rows free from competition from grasses for several years. Bottlebrush squirreltail was chosen over needle-and-thread grass as a companion species

Table 4. Soil Parameters at Three Locations Within the ESF at Completion of Demolition

\begin{tabular}{|c|c|c|c|c|c|c|c|c|c|}
\hline Location & Ph & $\begin{array}{c}P \\
(p \sin )\end{array}$ & $\begin{array}{c}\mathrm{K} \\
(\mathrm{pgm})\end{array}$ & $\begin{array}{c}\mathrm{N} \\
(\%)\end{array}$ & $\begin{array}{c}\text { Organic } \\
\mathrm{C}\left(\%_{0}\right)\end{array}$ & $\begin{array}{c}\text { CEC } \\
(\mathrm{meg} / 100 \mathrm{~g})\end{array}$ & $\begin{array}{l}\text { Sand } \\
\left(\Phi_{0}\right)\end{array}$ & $\begin{array}{l}\text { Silt } \\
(\%)\end{array}$ & $\begin{array}{l}\text { Clay } \\
(\%)\end{array}$ \\
\hline ESFPad & 7.8 & 8 & 234 & 0.02 & 0.14 & 63 & 54.7 & 39.9 & 5.4 \\
\hline ESF Mud Pit Area & 8.2 & 5 & 191 & 001 & 0.12 & 73 & 60.2 & 34.5 & 5.3 \\
\hline ESFMound & 82 & 6 & 187 & 0.01 & 0.14 & 10.7 & 57.9 & 36.5 & 5.7 \\
\hline
\end{tabular}


Table 5. Seeding Mixtures and Specifications for ESF and Boreholes RRL-2B and C

Species to be Seeded

Poa sandbergii

Sitanion hystrix

Artemisia tridentata tridentata

Chrysothamnus nauseosus

Chrysothamnus viscidiflorus

\begin{tabular}{c} 
Rate (kgha) \\
\hline 4.5 (PLS \\
2.2 (PLS) \\
0.28 \\
0.14 \\
0.14
\end{tabular}

\begin{tabular}{c} 
Depth of Seeding $(\mathrm{cm})$ \\
\hline $0.6-1.25$ \\
$0.6-1.25$ \\
broadcast \\
brondcast \\
broadcast
\end{tabular}

to Sandberg bluegrass because bottlebrush squirreltail was present in four of five plots surveyed in the surrounding habitat, whereas needle-and-thread was found in only one plot. Also, bottlebrush squirreltail may be one of the more effective native competitors with cheatgrass (Hironaka and Tisdale 1963). Seeding rates were based on information provided in Wasser and Shoemaker (1982). Seeding rates for Sandberg bluegrass and bottlebrush squirreltail were set relatively high to provide sufficient plants to compete effectively against both cheatgrass and the shrub species. Seeding depths were based on information in Fulbright et al. (1982) and Wasser and Shoemaker (1982).

\subsubsection{Mulching}

Mulches are commonly applied to soils to increase water retention and to decrease susceptibility to erosion (e.g., Scholl and Pase 1984). Organic mulches have the added benefit of stimulating mycorrhizal growth (Whitford 1988). Mycorrhizae are essential to the growth of many native plants in arid regions, buffering the plant against water and nutrient stress (Allen and Allen 1980).
Following the drilling of seed, a mulch of certified weed-free straw was to be blown over the seedbed at a rate of $4500 \mathrm{~kg} / \mathrm{ha}$ (2 Lons/acre), which is the rate specified by the Washington State Department of Transportation. The use of certified weed-free straw limits the introduction of weeds to the seedbed that would otherwise lower revegetation success (Evans et al. 1970). The mulch was crimped into the seedbed using a Finn Krimper. Mulching began November 16 and was completed by November 18, 1988 .

The actual rate of application based on a comparison of the amount of straw used to the amount of land mulched was $9000 \mathrm{~kg} / \mathrm{ha}$ ( 4 tons/acre). One effect of the excess mukh will be to further bias the carbon:nitrogen ratio, thus limiting the amount of nitrogen available to the growing plants. Also, the mulch may be too thick to allow the Sandberg bluegrass to emerge. Seeds of this species planted at depths of $3 \mathrm{~cm}$ or greater generally fail to emerge (Evans et al. 1977). Because the amount of mulch actually spread was not known until work was completed, it was not possible to rectify the situation without seriously damaging the seedbed.

Table 6. Specifications for Seed Used on the ESF and Boreholes RRL-2B and C

Species to be Seeded

Poa sandbergï

Sitanion hystrix

Artemisia tridentata tridentata

Chrysothamnus nauseosus

Chrysothamnus viscidiflorus

\begin{tabular}{|c|c|c|c|c|}
\hline & \multicolumn{4}{|c|}{ Percent } \\
\hline Origin (Stute) & Pure Seed & Weed & Iner & Gem \\
\hline $\mathbf{M T}$ & 96.44 & 0.19 & 3.08 & 95.00 \\
\hline UT & 72.98 & 030 & 26.47 & 75.00 \\
\hline UT & 14.86 & 0.00 & 85.14 & 79.00 \\
\hline UT & 1200 & 0.05 & 87.65 & 79.00 \\
\hline UT & 28.09 & 0.00 & 71.91 & 85.00 \\
\hline
\end{tabular}




\subsubsection{Planting}

Fifteen-cm tubeling spiny hopsage were planted on the ESF between March 8 and 15, 1989. The use of tubeling stock rather than attempting to establish plants from seed was based on the observation that no young hopsage plants have been identified anywhere on the Hanford Site, either in the extensive surveys performed for the BWIP borehole reclamation effort, nor anywhere else in at least the past 30 years. The use of tubeling stock has proved much more successful than the seeding of shrubs on other sites (Cook 1988).
Plants were set in the ground in a clumped configuration with each plant set in a depression at least $2.5 \mathrm{~cm}$ below grade. The depressions have a radius of approximately $17 \mathrm{~cm}$. Clumps consist of three tubelings in a triangular configuration with approximately $35 \mathrm{~cm}$ between plants. Clumped plants have higher survival and growth rates than plants set out in a more even pattern (MacMahon 1988) because of microclimatic changes and water harvesting by snow drifting caused by the clumped plants. Two liters of water were applied by hand to each tubeling at the time of planting to minimize planting shock.

Hopsage clumps were randomly distributed over the site at an average density of 89 clumps/ha. Shrub density was determined by calculating the existing number of shrubs per acre in the surrounding habitat and adding $30 \%$ to compensate for the tubeling mortality expected within the first year. Clump distribution patterns were derived by generating a sampling distribution from a Poisson population with a mean of $89 \mathrm{clumps} / \mathrm{ha}$. The resulting numbers were transferred to rough scale maps of the revegetation sites. The product was a map of clump numbers to be planted in each 55- by 55-ft square of the ESF and another map of clump number to be planted in each 50 - by 50 -ft square of boreholes RRL-2B and C (Figures 12 and 13).

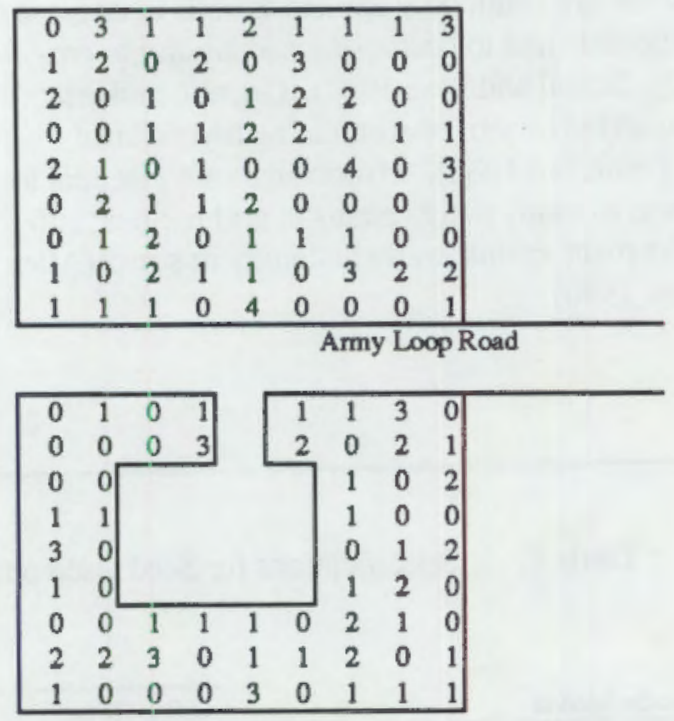

Figure 13. Schematic Diagram of Hopsage Clump Densities Planted at the Boreholes RRL$2 B$ and $C$ (numbers refer to number of clumps to be planted per $\sim 15 \mathrm{~m} / \mathrm{side}$ squares.) 


\subsubsection{Irrigation}

The ESF was irrigated using hand-moved sprinklers during March to June of 1989 . Irrigation was done at the end of each month sufficient to make the cumulative precipitation on the site reach $2.5 \mathrm{~cm}$ per month. This low amount of added moisture was chosen to provide sufficient moisture to aid in grass establishment but not enough to encourage the growth of unwanted species or to overstimulate growth of the seeded species. 



\subsection{RECLAMATION SUCCESS}

The progress of the reclamation program at the ESF and associated boreholes RRL-2B and C was tracked by periodic checks as construction and revegetation advanced. A quantitative examination of the germination and growth of plants on the seeded areas was conducted in the spring of 1989 before the summer dormancy period of the native grasses. The data derived from this examination were examined and compared to data obtained from quantitative surveys of four control plots established around the perimeter of the ESF.

\subsection{DEMOLITION}

At completion of demolition, all man-made materials had been removed from above the original ground surface. A small portion of the pad at borehole RRL- $2 \mathrm{C}$ was retained to provide monitoring access to the well head. The mound over the drill rig foundation and shaft collar was made up of materials (rock, gravel, and sand) salvaged from the removal of the top course at the ESF. This material is low in nutrients and organic matter, and consequently has poor water retention characteristics. A second small mound was left over another piece of concrete foundation unexpectedly encountered in the southeast quarter of the ESF. Otherwise, the seedbed consisted primarily of native soils. An aerial photograph of the reclamation site taken on December 14,1988 , is reproduced in Figure 14.

\subsection{VEGETATION}

To track the development of vegetation in the target habitats, data on percent cover and plant density were obtained from the four control plots located around the ESF in May and June of 1988. Stakes marking the plot located near borehole RRL-2B in May 1988 were inadvertently removed during construction site clean-up, thereby preventing further monitoring at that plot (see Section 2.2.2). The RRL-2B plot was the only one of the original five in which hopsage occurred. Vegetative cover and density in the control plots were assessed using the same methods described previously. Plant cover was measured on April 6 and again on June 12, 1989 (Table 7), as were species tallies (Table 8). Shrub density was measured on June 12 (Table 9). Unsummarized data are presented in Appendix B.

Native grasses composed relatively little of the ground cover in the undisturbed habitat. Bottlebrush squirreltail was the most common native grass in the habitat, although it contributed relatively little of the ground cover. Indian ricegrass and Sandberg bluegrass were relatively more scarce. Needle-and-thread grass did not occur in the plots. The most common shrubs on the plots were big sagebrush and green rabbitbrush, though the average density of grey rabbitbrush across the four plots was very much greater than the other two species. Native forbs constituted a small portion of the total ground cover, but occurred throughout the habitat. Forbs found on the plots included hoary aster (Machaeranthera canescens), winged cryptantha (Cryptantha pterocarya), broom buckwheat (Eriogonum viminewm), white-stemmed globe-mallow (Sphaeralcea munroana), turpentine cymopterus (Cymopterus terebinthinus), and yellow salsify (Tragopogon dubius).

Table 7. Percent Cover for Plants in ESF Control Plots (N=4) in April and June 1989

\begin{tabular}{|c|c|c|c|}
\hline \multirow[b]{2}{*}{ Dave } & \multirow[b]{2}{*}{ Species } & \multicolumn{2}{|c|}{ Peroent Cover } \\
\hline & & Mean & Std.Dev. \\
\hline \multirow[t]{8}{*}{ April } & Ambrosia acanthicarpa & 0.25 & 0.50 \\
\hline & Artemisia tridentata & 6.50 & 4.70 \\
\hline & Bromus tectorum & 27.50 & 810 \\
\hline & Chrysothamnus nauseosus & 7.00 & 8.10 \\
\hline & Chrysothamnus viscidiflorus & 0.25 & 0.50 \\
\hline & Cryptanthapterocarya & 1.50 & 3.00 \\
\hline & Cymopterus terebinthinus & 1.25 & 250 \\
\hline & Draba verna & 0.25 & 0.50 \\
\hline \multirow[t]{7}{*}{ June } & Artemisia tridentata & 7.00 & 4.80 \\
\hline & Bromus tectorum & 43.50 & 16.50 \\
\hline & Chrysothamnus nauseosus & 6.75 & 7.90 \\
\hline & Chrysothamnus viscidiflorus & 0.25 & 0.50 \\
\hline & Cymopterus terebinthinus & 7.25 & 8.80 \\
\hline & Oryzopsis hymenoides & 0.25 & 0.50 \\
\hline & Sitanion hystrix & 0.50 & 1.00 \\
\hline
\end{tabular}




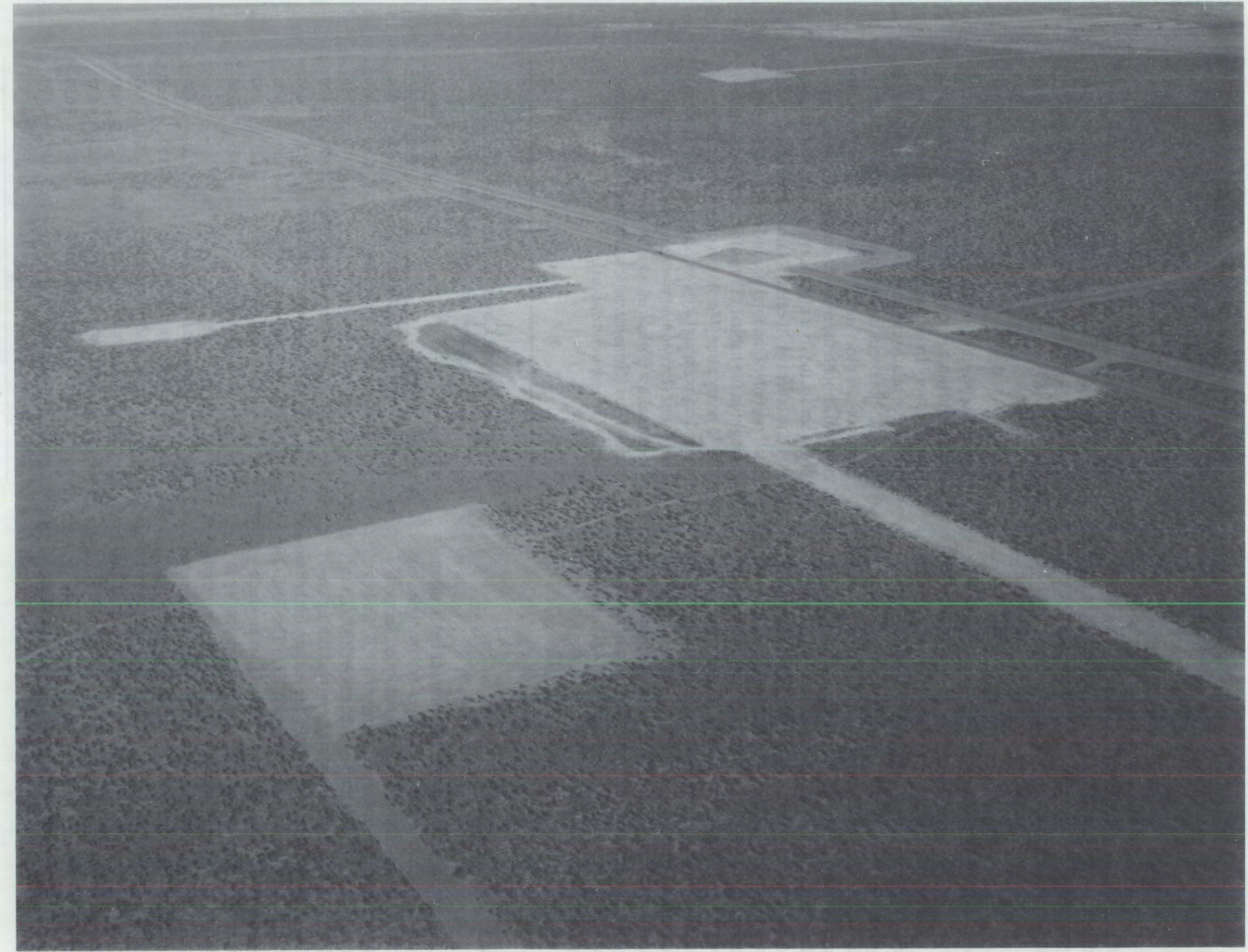

Figure 14. Aerial Photograph of the ESF and Associated Boreholes at Completion of Deconstruction, December 1988 
Table 8. Species Occurring in ESF Control Plots (N=4) in April and June 1989

Species

Ambrosia acanthicarpa

Percent of Plots

Artemisia tridentata

Bromus tectorum

Chrysothamnus nauseosus

Chrysothamnus viscidiflorus

Cryptantha ptereocarya

Cymopterus terebinthinus

Draba verna

Eriogonum vimineum

Machaer anthera canescens

Oryzopsis hymenoides

Poa sandbergii

Salsolakali

Sitanion hystrix

Sphaeralcea munroana

The primary alien species in the control plots was cheatgrass, which occurred in all plots. This annual grass grew rapidly between April and June, going from nearly $28 \%$ to nearly $50 \%$ of the ground cover in that time period. Other annuals present in the control plots were bur ragweed (Ambrosia acanthicarpa), Russian thistle (Salsola kali), and spring whitlow-grass (Draba verna). All are non-native species. Whitlow-grass is a snall member of the mustard family (Cruciferae) seldom reaching more than $5 \mathrm{~cm}$ in height. It constitutes only a small fraction of undisturbed plant community at the ESF. Native to Eurasia, spring whitlowgrass flowers in May on the Hanford Site. Cheatgrass flowers in April and sets seed in May and June. Ragweed and Russian thistle set seed later in the summer.

Table 9. Density of Shrubs Occurring in ESF Control Plots (N=4), June 12, 1989

Species

Artemisia tridentata

Chrysothamnus nauseosus

Chrysothamnus viscidiflorus
All the alien species in the control plots are early succession colonizers expected to invade the revegetated area at some time. Because of their late seed-set, ragweed and Russian thistle are likely to be present before the other invasive species and in greater number during the first year. Because of the large amount of cheatgrass in the surrounding habitat, however, cheatgrass is expected to replace the other annuals on the revegetated site within several years.

Vegetative growth on the revegetated areas was measured on March 30,1989, by a stratified random sampling of 60 plot frames $\left(0.25 \mathrm{~m}^{2}\right)$ located within six major strata. Substrata were distributed evenly over each major stratum, with one plot located randomly within each substratum such that 8 plots were sampled on the ESF access road, 6 on the ESF mound, 28 on the main ESF pad, 4 on the RRL-2B overflow pond area and its access road, 7 on the RRL-2B pad area, and 7 on the RRL-2C pad area. All plants growing within the plot frames were counted by species by the number of leaves present. Average height of each species was recorded. Because the plants were immature, it was seldom possible to identify grasses or forbs to species, so most observations were lumped as Poa/Sitanion or Forb. Spatial comparisons of grass development at the ESF and related boreholes are presented in Figures 15, 16, and 17; data summaries are presented in Appendix C.

Differences among strata on the basis of grass density were statistically significant (square-root-transformed data: $F_{5,54}=3.785, p=0.0052$ ); strata

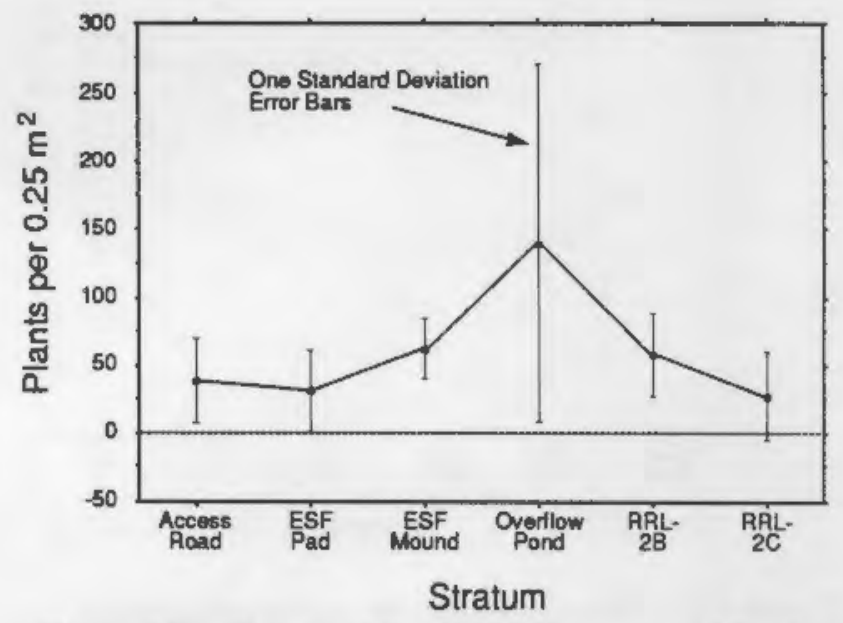

Figure 15. Density of Sandberg Bluegrass and Bottlebrush Squirreltail (Combined) per $0.25-\mathrm{m}^{2}$ on the ESF and Associated Boreholes in March 1989 


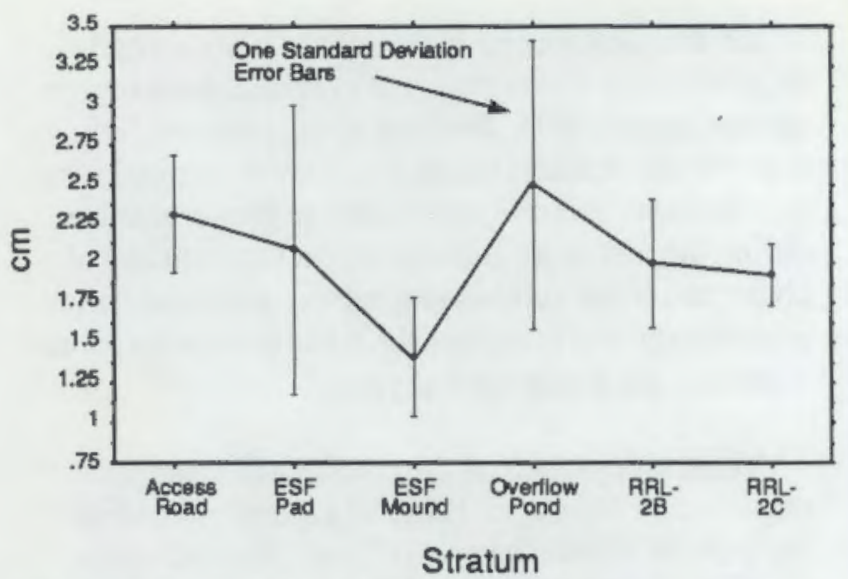

Figure 16. Height of Sandberg Bluegrass and Bottlebrush Squirreltail (Combined) in $0.25-\mathrm{m}^{2}$ Plots on the ESF and Associated Boreholes in March 1989

showed no statistically significant differences in plant height or number of leaves per plant due in part to the large variation in the data. The density of native grasses on the overflow pond area was greater on average than in any of the other strata (Figure 16), though variability within the stratum was extensive. Grass on the mound was shorter than grass elsewhere, though the difference was not statistically significant.

The overflow pond area differed in treatment from the other sites only in that seed was drilled in along an

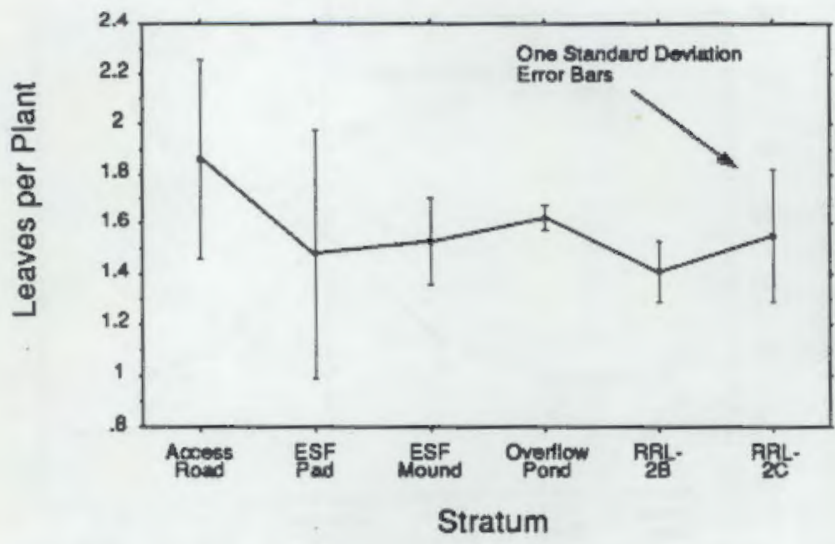

Figure 17. Average Number of Leaves of Sandberg Bluegrass and Bottlebrush Squirreltail (Combined) in $0.25-\mathrm{m}^{2}$ Plots on the ESF and Associated Boreholes in March 1989 east-west axis, whereas the remaining strata were drilled on a north-south axis. Differences in plant growth cannot be unambiguously attributed to treatment differences, however, since the overflow area differed from the other strata on other bases as well. For example, the overflow area had a much larger edge-to-size ratio than the other strata. A large ratio would buffer the seedlings from winds, thereby protecting them from soil erosion and wind chill. Differences in soil may also have been present: the overflow area was never covered over with a gravel pad, and had some vegetative growth at the start of restoration. Thus the soil on the overflow area could be expected to have a higher proportion of naturally occurring soil microorganisms which would enhance nutrient cycling (Whitford 1988).

The ESF mound had no fewer plants than other areas and showed no greater spatial variability in plant density than in other areas, indicating no significant effects of soil type on emergence. Plants on the mound were smaller in stature than elsewhere, though there were no differences in leaf number. Plants on the mound would experience more severe winds than plants growing in the lowlands. Repeated exposure to high winds can cause temporary or even permanent dwarfing in many plants. Soils with large proportions of sand and gravel also have lower water-holding capacity than soils made up of finer particles or with a good fraction of organic material (Bradshaw and Chadwick 1980).

Seeded shrubs were 100 immature in March to allow differentiation between seeded shrubs and volunteer dicot herbs, consequently, no information on growth of big sage or either of the rabbitbrushes can be provided in this report. Survival of spiny hopsage tubelings was determined by walking eight east-west transects across the ESF area, noting the number of planted shrubs along the transect and indicating which appeared alive and which did not. Transects were surveyed on July 13,1989. Overall, apparent hopsage mortality during the first 4 months on the site averaged $51.5 \%$. Mortality was higher in the center of the ESF than at the edges (Figure 18), though the difference was not statistically significant $\left(F_{2,18}=2.341\right.$, $p=0.12$ ). There also was no difference in mortality between north and south sections of the site $\left(\mathrm{F}_{1,18}=\right.$ $0.642, p=0.43$ ). Most of the apparent shrub mortality was due to depredation by black-tailed jackrabbits (Lepus californicus); it remains to be seen whether or not the plants that have been grazed have sufficient nutrient reserves to regenerate. 


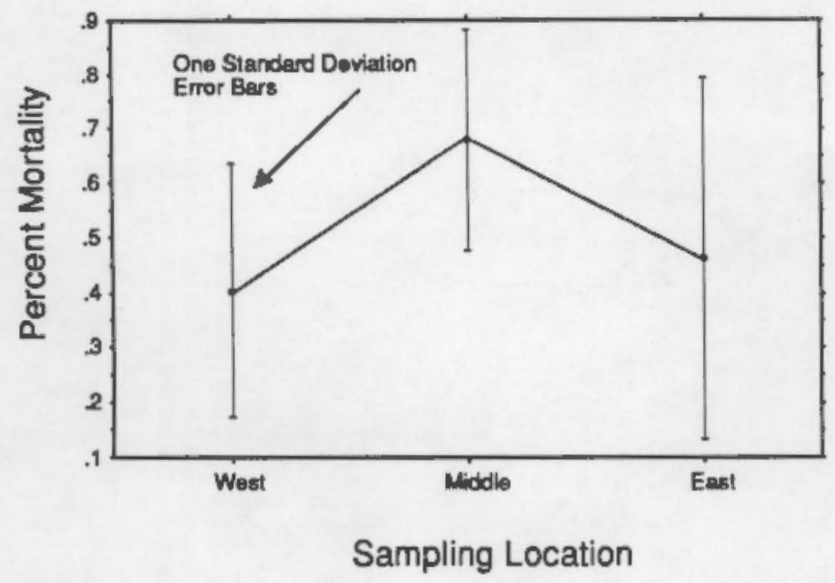

Figure 18. Average Mortality of Tubeling Hopsage Between Planting in March and Assessment in July 1989 



\subsection{CONCLUSION AND ASSESSMENT OF SUCCESS}

Revegetation of the ESF and its associated boreholes RRL-2B and C is in its early stages. Work is completed, but insufficient time has elapsed to allow meaningful determination of the success of that work. Seeded vegetation has yet to complete a full growth year. All species of grasses that were seeded are cold-season grasses, that is, they are photosynthetically active during the colder, wetter months between late October and early May. During the remainder of the year they are dormant, with little evidence of photosynthetic activity. To remain viable, plants must stockpile sufficient stores of nutrients, water, and energy during the growing season to carry them through the rest of the year. Consequently, the dry, hot summer months constitute the most rigorous period in the early life of these plants. An assessment of plant mortality at the beginning of the second growing season will provide a much better indication of the success of the revegetation effort than that currently available.

That caveat aside, some general conclusions and predictions may be made regarding the course of succession at the ESF. As of March 1989, cover by seeded grasses was consistent with the reclamation objective. Emergence was spotty, with many plots showing no grasses at all. Growth of grasses on the mound was poorer than elsewhere, though emergence rates were no different. An extremely low temperature arctic air mass entered the Pasco Basin in February, with temperatures below $-25^{\circ} \mathrm{C}$. Most of the grasses showed frost burns from this low-temperature event. Damage appeared sufficiently severe that many plants deemed alive at the end of March were unlikely to survive another month. Whether or not sufficient grasses survive cannot be assessed until the fall 1989 growth period.

No data are available to estimate the success of seeding of shrubs. By July 1989, young plants of grey rabbitbrush were noted on the pad area, and young big sagebrush were found on the access road. The actual density of plants will not be assessed until fall 1989. Mortality of hopsage was greater than that anticipated in the design phase. However, hopsage is such a small portion of the native community that the number of plants still alive in March were consistent with the reclamation objective. Depredation by jackrabbits can be expected to deplete the numbers of shrubs growing on the site over the next several years. Depredation control measures, such as the use of wire cages over young shrubs, may be warranted. The need for such treatment will become evident within the first year of growth. Further monitoring of the site will be needed before conclusions can be made regarding attaining the reclamation objective or the need for remedial action.

By July 1989 , the site supported a large number of alien forbs, including Russian thistle, ragweed, and tumble mustard. This colonization was not unexpected. Extensive data have been gathered on plant succession at coal mine reclamation sites in semiarid regions of Montana and Wyoming by DePuit and Redente (1988). Their results indicate three distinct phases in succession at revegetation sites. First, the site is heavily invaded by ahen annual forbs such as Russian thistle, tumble mustard, and ragweed. On sites with sufficient nutrients available in the soil, this colonization peaks within the first several years at something on the order of $50 \%$ to $60 \%$ alien annuals. Within 6 years, the number of alien annual forbs dechines to very low levels (Figure 19). Second, seeded grasses increase in numbers to compose up to $40 \%$ of species after 3 to 4 years. Cheatgrass can also be expected to show a similar increase, at least at the ESF. Third, planted shrubs begin to increase in numbers after 4 to 5 years but remain at intermediate levels thereafter. Native forbs, such as Carey's balsamroot, invade the area within the same period but never reach significant proportions.

Cheatgrass remains the primary potential spoiler at the ESF. In terms of the reclamation goal set for the site, the presence of cheatgrass would not be inappropriate; however, dense stands of cheatgrass will impede the development of shrub cover. This may be especially likely for the mound area. Although no one of the problems encountered during revegetation (excessive wood fiber, late seeding, excessive mulch, cold) may individually have affected success, the cumuiative effect may become significant. Without careful management, the mound area may revert to a pure stand either of cheatgrass, or of shrubs (see Figure 11). Whether or not such an event will occur may not become evident for several more growing seasons. 


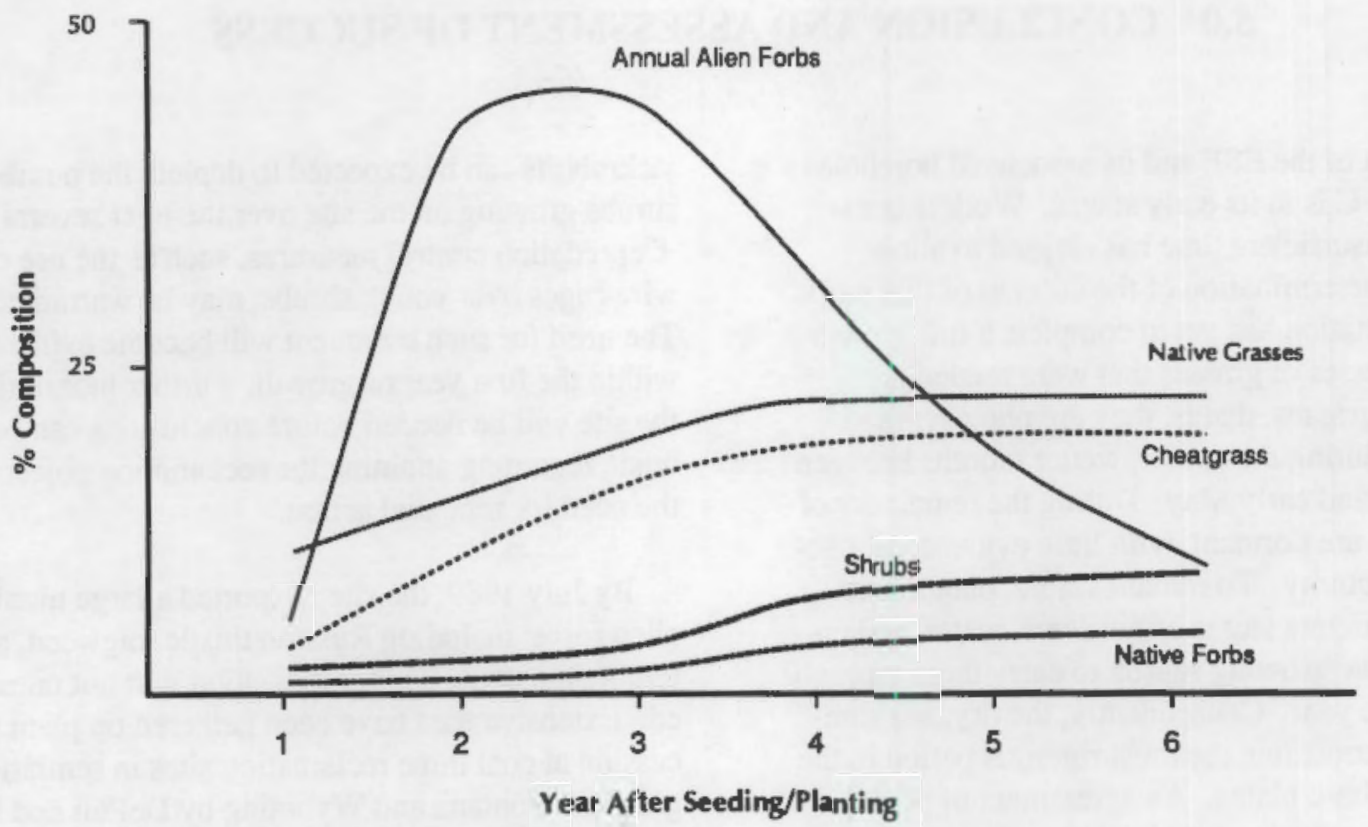

Figure 19. Successional Profiles Expected at BWIP Reclamation Sites (modified from DePuit and Redente 1988) 


\subsection{REFERENCES}

Allen, E. B. 1988. "Some Trajectories of Succession in Wyoming Sagebrush Grassland: Implicalions for Restoration." In The Reconstruction of Disturbed Arid Lands, ed. E. B. Allen, pp. 89-112. Westview Press, Boulder, Colorado.

Allen, M. F., and E. B. Allen. 1980. "Natural Re-establishment of Vesicular-Arbuscular Mycorthizae Following Stripmine Reclamation in Wyoming." J. Appl. Ecol. 17:139-147.

Babad, H. 1985. The Basal Waste Isolation Project: An Update. RHO-BW-SA-459, Rockwell Hanford Operations, Richland, Washingion.

Biondini, M. E., C. D. Bonham, and E. F. Redente. 1985. "Secondary Successional Patterns in a Sagebrush (Artemisia tridentata) Community as They Relate to Soil Disturbance and Soil Biological Activity." Vegetatio 60:25-36.

Bradshaw, A. D., and M. J. Chadwick. 1980. The Restoration of Land. University of California Press, Berkeley, Califomia.

Chatters, J. C., ed 1989. Hanford Cultwal Resowrces Management Plan. PNL.6942, Pacific Northwest Laboratory, Richland, Washington.

Chapin, F. S., III. 1980. "The Mineral Nutrition of Wild Planls." Ann. Rev. Ecol. Syst. 11:233-260.

Cook, C. W. 1988. "Has Research Contributed Significanly to Mined Land Reclamation?" In Proceedings: High Altitude Revegetation Workshop No.8, eds. W. R. Keammerer and L. F. Brown, pp. 230-239. Colorado State University, For Collins, Colorado.

Cushing, C. E. 1987. Hanford Site National Environmental Policy Act (NEPA) Characterization. PNL-6415, Pacific Norhwest Laboratory, Richland, Washington.

Daubenmire, R, 1970. Steppe Vegetation of Washington. Technical Bulletin 62, Washington Agricultural Experiment Station, Pullman, Washingin.
Deju, R. A. 1978. Basalt Waste Isolation Program. RHO-BWI-SA-2, Rockwell Hanford Operations, Richland, Washington.

DePuit, E. J., and M. M. Caldwell. 1973. "Seasonal Patlem of Net Photosynthesis of Artemisia tridenLath" Am. J. Botany 60:426-435.

DePuit, E. J., and E. F. Redente. 1988. "Manipulation of Ecosystem Dynamics on Reconstructed Semiarid Lands." In The Reconstruction of Disturbed Arid Lands, ed. E. B. Allen, pp. 162-204. Westview Press, Boulder, Colorado.

Evans, R.A., H. R. Holbo, R. E. Eckert, and J. A. Young. 1970. "Functional Environment of Downy Brome Communities in Relation to Weed Control and Revegetation." Weed Sci.J. 18:154161.

Evans, R. A., and I. A. Young. 1986. "Germination Profiles for Five Populations of Big Sagebrush." In Proceedings-Symposium of the Biology of Artemisia and Chrysothannus, eds. E. D. McArthur and B. L. Welch, pp. 366-369. General Technical Report INT-200, U.S. Department of Agriculture, Washington, D.C.

Evans, R. A., J. A. Young, and B. A. Roundy. 1977. "Seedbed Requirements for Germination of Sandberg Bluegrass." Agronomy Journal 69:817-820.

Fulbright, T. E., E. F. Redente, and N. E. Hargis. 1982. Growing Colorado Plants from Seed: A State of the Ant Vol. II: Grasses and Grasslike Plants. Research Report FWS/OBS-82/29. U.S. Dept Int., Fish Wildl. Serv., Washington, D.C.

Goodall, D. W. 1953. "Point-Quadrat Methods for the Analysis of Vegetation." Australian J. Botany 1:457-461.

Haferkamp, M. R., D. C. Ganskopp, R. R. Milles, and F. A. Sneva. 1987. "Drilling Versus Imprinuing for Establishing Crested Wheatgrass in the Sagebrush-bunchgrass Steppe." J. Range Manoge. 40:524-530. 
Hinds, W. T., and J. M. Thorp. 1972. Pacific Northwest Laboratory Annual Report for 1971 to the USAEC Division of Biology and Medicine. BNWL-1650, Part 2, Pacific Northwest Laboratory, Richland, Washinglon.

Hironake, M., and E. W. Tisdale. 1963. "Secondary Succession in Annual Vegetation in Southem Idaho." Ecology 44:810-812.

MacMahon, J. A. 1988. "Restoralion and Studies of Succession and Community Architecture." In Proceedings: High Altitude Revegetation Workshop No. 8, eds. W. R. Keammerer and L. F. Brown, pp. 1. Colorado State University, Fort Collins, Colorado.

Rasmussen, J. J. 1971. Soil Survey, Benton County Area, Washington. U.S. Department of Agriculture, Soil Conservation Service, Washington, D.C.

Redente, E. F., T. B. Doer, C. E. Grygiel, and M. E Biondini. 1984. "Vegetation Establishment and Succession on Disturbed Soils in Northwest Colorado." Reclam. Reveg. Res. 3:153-165.

Rickard, W. H., Jr. 1988. Natural Vegetarion at the Proposed Reference Repository Location in Southeastern Washington. PNL-6402, Pacific Northwest Laboralory, Richland, Washingion.

Rickard, W.H., Jr., and R. H. Sauer. 1982. "Self-Revegetalion of Disturbed Ground in the Deserts of Nevada and Washington." Northw. Sci.56:41-47.

Rickard, W. H., Jr., and C. A. Schuler. 1988. Descriptions of Plant Communities at the Proposed Reference Repository Loconion and Implications for Reclamation of Disturbed Ground. PNL 6494, Pacific Northwest Laboratory, Richland, Washington.

Rickard, W. H., Jr., and B. E. Vaughan. 1989. "Plant Communities: Characteristics and Responses." In Shrub-Steppe: Balance and Change in a SemiArid Terrestrial Ecosystem, eds. W. H. Rickard, Jr., L. E. Rogers, B. E. Vaughan, and S. F. Liebetrall, pp. 109-181. Elsevier, Amsterdam.

Scholl, D. G., and C. P. Pase. 1984. "Wheatgrass Response to Organic Amendments and Contour Furrowing on Coal Mine Spoil." J. Environ. Qual. 3:470-482.
Smith, P. L., E. F. Redente, and E. Hooper. 1987. "Soil Organic Matter." In Reclaiming Mine Soils and Overburden in the Western United States, eds R. D. Williams and G. E. Schumand, pp. 185-214. Soil Conservation Society of America, Ankeny, Iowa.

Stone, W. A., J. M. Thorp, O. P. Gifford, and D. J. Hoitink. 1983. Climatological Summary for the HanfordArea. PNL-4622, Pacific Northwest Laboratory, Richland, Washington.

Thorp, J. M., and W. T. Hinds. 1977. Microclimates of the Arid Lands Ecology Reserve, 1968-1975. BNWL-SA-6231, Pacific Northwest Laboratory, Richland, Washington.

Toy, T. J., and D. Shay. 1987. "Comparison of Some Soil Properties on Natural and Reclaimed Hillslopes." Soil Sci. 143:64-277.

U.S. Department of Energy (DOE). 1978. Environmental Assessment, National Waste Terminal Storage Program, Near Surface Test Facility, Hanford Reservation, Washington. DOE/EA0052 , U.S. Department of Energy, Washington, D.C.

U.S. Deparument of Energy (DOE). 1982. Environmentol Assessment, National Waste Terminal Storage Program, Exploratory Shaft Construction, Hanford Reservation, Washington. DOE/EA-0188, U.S. Deparment of Energy, Washington, D.C.

U.S. Department of Energy (DOE). 1985. Mission Plan for the Civilian Radioactive Waste Management Program (Vol 1). DOE/RW-0005, U.S. Department of Energy, Office of Civilian Radioactive Waste Management, Washington, D.C.

U.S. Department of Energy (DOE). 1986. Envirommental Assessment, Reference Repository Lacation. Hanford Site, Washington. DOE/RW-0070, U.S. Department of Energy, Office of Civilian Radioactive Waste Management, Washington, D.C.

Vier, S. R. 1985. "A New Instrument for Measuring Ground Cover Based on the Point-Hit Technique The Optical Bar." In Annual Meeting of the American Sociery of Surface Mining and Reclamation, Denver, Colorado. 
Wasser, C. W,, and J. Shoemaker. 1982. Ecology and Culture of Selected Species Useful in Revegetating Disturbed Land in the West. Research Report FWS/OBS-82/56. U.S. Dept. InL Fish Wildl. Serv., Washington, D.C.

Whitford, W, G. 1988. "Decomposition and Nutrient Cycling in Disturbed Arid Ecosysterns." In The Reconstruction of Disturbed Arid Lands, ed. E. B. Allen, pp. 136-161. Westview Press, Boulder, Colorado.

Wood, M. K., R. W. Knight, and J. A. Young. 1976. "Spiny Hopsage Germination." J, Range Marage. 29:53-56.

Young, J. A., and R. A. Evans. 1977. "Squirreltail Seed Germination." J.Range Manage. 30:33-36. 


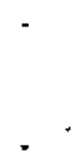

. 


\begin{abstract}
APPENDIX A
DATA ON UNDISTURBED HABITATS AT THE EXPLORATORY SHAFT

FACILITY BETWEEN MAY 11 AND JUNE 21, 1988
\end{abstract}




\section{APPENDIX A}

\section{DATA ON UNDISTURBED HABITATS AT THE EXPLORATORY SHAFT FACILITY BETWEEN MAY 11 AND JUNE 21, 1988}

The following is a summary of the field data collected between May 11 and June 21, 1988, from undisturbed habitat surrounding the Exploratory Shaft Facility.

\section{Transect Data Percent Cover}

\begin{tabular}{|c|c|c|c|}
\hline Location & Sample Date & Species & \% Cover \\
\hline \multirow[t]{7}{*}{ ESF \#1 } & $5 / 11 / 88$ & Bromus tectorum & 36 \\
\hline & & Chrysothamnus nauseosus & 13 \\
\hline & $6 / 21 / 88$ & Bromus tectorum & 34 \\
\hline & & Poa sandbergii & 1 \\
\hline & & Stipa comata & 1 \\
\hline & & Chrysothamnus nauseosus & 13 \\
\hline & & Cryptantha circumcissa & 10 \\
\hline \multirow[t]{4}{*}{ ESF \#2 } & $5 / 11 / 88$ & Bromus tectorum & 63 \\
\hline & & $\begin{array}{l}\text { Poa sandbergii } \\
\text { Artemisia tridentata }\end{array}$ & $\begin{array}{l}1 \\
3\end{array}$ \\
\hline & $6 / 21 / 88$ & Bromus tectorum & 64 \\
\hline & & Artemisia tridentato & 8 \\
\hline \multirow[t]{5}{*}{ ESF \#3 } & $5 / 11 / 88$ & Bromus tectorum & 34 \\
\hline & & Artemisia tridentata & 13 \\
\hline & $6 / 21 / 88$ & Bromus tectorum & 32 \\
\hline & & $\begin{array}{l}\text { Artemisia tridentata } \\
\text { Cymonterus terebinthinus }\end{array}$ & $\begin{array}{r}23 \\
3\end{array}$ \\
\hline & & Sphaeralcea munroana & 1 \\
\hline \multirow[t]{4}{*}{ ESF \#4 } & $6 / 21 / 88$ & Bromus tectorum & 48 \\
\hline & & Artemisia tridentata & 13 \\
\hline & & Chrysothamnus nauseosus & 10 \\
\hline & & Chrysothamnus viscidiflorus & 5 \\
\hline \multirow[t]{2}{*}{ RRL-2B } & $5 / 13 / 88$ & Bromus tectorum & 26 \\
\hline & & $\begin{array}{l}\text { Artemisia tridentata } \\
\text { Chrosothamnus nauseosus }\end{array}$ & $\begin{array}{l}4 \\
7\end{array}$ \\
\hline
\end{tabular}


Plot Data - Shrub Density

\begin{tabular}{lllr} 
Location & Sample Date & \multicolumn{1}{c}{ Species } & \#per 0.01 ha \\
ESF \#1 & $5 / 11 / 88$ & Chrysothamnus nauseosus & 83 \\
& & Chrysothamnus viscidiflorus & 5 \\
& $6 / 21 / 88$ & Chrysothamnus nauseosus & 74 \\
& & Chrysothamnus viscidiflorus & 2 \\
ESF \#2 & $5 / 11 / 88$ & Artemisia tridentata & 23 \\
& $6 / 21 / 88$ & Artemisia tridentata & 20 \\
ESF \#3 & $5 / 11 / 88$ & Artemisia tridentata & 21 \\
& $6 / 21 / 88$ & Artemisia tridentata & 22 \\
ESF \#4 & $6 / 21 / 88$ & Artemisia tridentata & 10 \\
& & Chrysothamnus nauseosus & 297 \\
& & Chrysothamnus viscidiflorus & 10 \\
RRL-2B & $5 / 13 / 88$ & Artemisia tridentata & 6 \\
& & Atriplex spinosa & 1 \\
& & Chrysothamnus nauseosus & 48
\end{tabular}


APPENDIX B

DATA ON UNDISTURBED HABITATS AT THE EXPLORATORY SHAFT FACILITY ON APRIL 6 AND JUNE 12, 1989 


\section{APPENDIX B}

\section{DATA ON UNDISTURBED HABITATS AT THE EXPLORATORY SHAFT FACILITY ON APRIL 6 AND JUNE 12, 1989}

The following is a summary of the field data collected on april 6 and June 12, 1989, from undisturbed habitat surrounding the Exploratory Shaft Facility.

\section{Transect Data $=$ Percent Cover}

Location Sample Date
ESF \#

ESF \#2

ESF \#4

$4 / 6 / 89$

$6 / 12 / 89$

ESF \#3

6/12/89

$4 / 6 / 89$

$6 / 12 / 89$

$4 / 6 / 89$

$6 / 12 / 89$
Species

Bromus tectorum

Chrysothamnus nauseosus

Cryptantha pterocarya

Ambrosia acanthicarpa

Bromus tectorum

Oryzopsis hymenoides

Chrysothamnus nauseosus

Cymopterus terebinthinus

Bromus tectorum

Draba verna

Artemisia tridentato

Bromus tectorum

Artemisia tridentata

Bromus tectorum

Artemisia tridentata

Cymopterus terebinthinus

Bromus tectorum

Artemisia tridentata

Cymopterus terebinthinus

Sitanion hystrix

Bromus tectorum

Artemisia tridentato

Chrysothamnus nauseosus

Chrysothamnus viscidiflorus

Bromus tectorum

Artemisia tridentato

Chrysothamnus nauseosus

Chrysothamnus viscidiflorus
\% Cover

25

15

6

1

37

1

12

18

39

1

66

11

20

7

5

27

8

11

1

26

11

13

I

44

9

15 


\section{Plot Data - Shrub Density}

\begin{tabular}{lllc} 
Location & Sample Date & \multicolumn{1}{c}{ Species } & \#per 0.01 ha \\
ESF \#1 & $6 / 12 / 89$ & Chrysothamnus nauseosus & 65 \\
& & Chrysothamnus viscidiflorus & 3 \\
ESF \#2 & $6 / 12 / 89$ & Artemisia tridentata & 20 \\
& & Chrysothamnus viscidiflorus & 1 \\
ESF \#3 & $6 / 12 / 89$ & Artemisia tridentata & 22 \\
ESF \#4 & $6 / 12 / 89$ & Artemisia tridentata & 10 \\
& & Chrysothamnus nauseosus & 246 \\
& & Chrysothamnus viscidiflorus & 10
\end{tabular}




\section{APPENDIX C}

SUMMARY OF GROWTH PARAMETERS OF GRASSES SEEDED ON THE EXPLORATORY SHAFT FACILITY IN MARCH I989 


\begin{abstract}
APPENDIX C
SUMMARY OF GROWTH PARAMETERS OF GRASSES SEEDED ON THE EXPLORATORY SHAFT FACILITY IN MARCH 1989
\end{abstract}

The following is a summary of the field data collected in March 1989 from the revegetated Exploratory Shaft Facility and Boreholes RRL-2B and C. These data reflect growth parameters of seeded grasses.

Parameter Location Count Mean Std. Dev Std. Error

Plant Density per $0.25 \mathrm{~m}^{2}$

$\begin{array}{lcccc}\text { Access Road } & 8 & 38.1 & 31.4 & 11.1 \\ \text { ESF Pad } & 28 & 30.9 & 29.8 & 5.6 \\ \text { ESF Mound } & 6 & 62.3 & 22.3 & 9.1 \\ \text { Overflow Pond } & 4 & 139.2 & 131.3 & 65.7 \\ \text { RRL-2B } & 7 & 57.9 & 31.0 & 11.7 \\ \text { RRL-2C } & 7 & 27.1 & 32.6 & 12.3\end{array}$

Plant Height (cm)

$\begin{array}{lcccc}\text { Access Road } & 8 & 2.3 & 0.37 & 0.13 \\ \text { ESF Pad } & 28 & 2.1 & 0.91 & 0.17 \\ \text { ESF Mound } & 6 & 1.4 & 0.38 & 0.15 \\ \text { Overflow Pond } & 4 & 2.5 & 0.91 & 0.46 \\ \text { RRL-2B } & 7 & 2.0 & 0.41 & 0.15 \\ \text { RRL-2C } & 7 & 1.9 & 0.19 & 0.07\end{array}$

Leaf Number Per Plant

$\begin{array}{lcccc}\text { Access Road } & 8 & 1.9 & 0.40 & 0.14 \\ \text { ESF Pad } & 28 & 1.5 & 0.49 & 0.09 \\ \text { ESF Mound } & 6 & 1.5 & 0.18 & 0.07 \\ \text { Overflow Pond } & 4 & 1.6 & 0.05 & 0.02 \\ \text { RRL-2B } & 7 & 1.4 & 0.12 & 0.05 \\ \text { RRL-2C } & 7 & 1.6 & 0.26 & 0.10\end{array}$




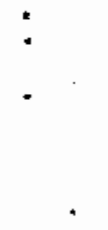




\section{DISTRIBUTION}

No. of

Copies

\section{OFESITE}

2 DOE/Office of Scientific and Technical Information

\section{ONSITE}

\section{DOE Richland Operations Office}

J. H. Antonen

J. D. Furubotten

A. G. Lassila

5 Westinghouse Hanford Company

C. R. Haggerty

D. E. Mahagin

J. E. Thrasher

P. H. Turner

BWIP Records Center

4 Kaiser Engineers Hanford

K. C. Burgard

R. E. Grant

N. M. Hutchins

R. L. Newell
No. of

Copies

45 Pacific Northwess Laboratory

R. W. Bienert

C. A. Brandt (10)

N. A. Cadoret

D. D. Dauble

J. W. Falco

R. H. Gray (5)

J. M. Hales

P. C. Hays

M. G. Hefty

T. L. Page

W. T. Pennell

W. H. Rickard, Jr. (10)

L. E. Rogers

R. L. Skaggs

J. B. States

H. E. Westerdahl

R. K. Woodruff

Publishing Coordination

Technical Report Files (5) 
